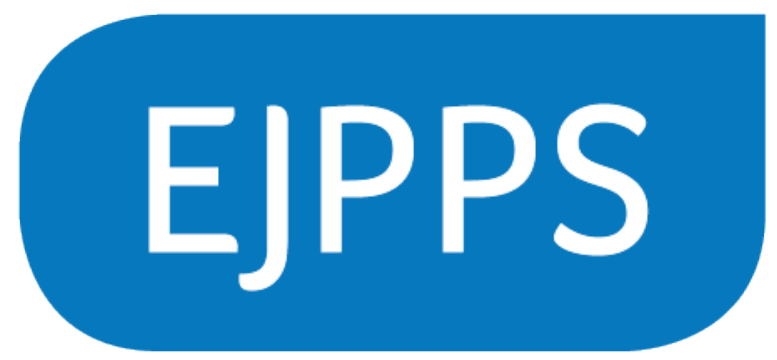

\begin{tabular}{|l} 
EUROPEAN JOURNAL OF \\
PARENTERAL AND \\
PHARMACEUTICAL SCIENCES
\end{tabular}

EJPPS - European Journal of Parenteral and Pharmaceutical Sciences Volume 24 Issue 3

https://www.ejpps.online/use-of-hazard-analysis-critical-con

https://doi.org/10.37521/ejpps.24302

Use of Hazard Analysis Critical Control Point (HACCP) methodology for biocontamination control: Assessing microbial risks and to determining environmental monitoring locations

By Tim Sandle*, Monica Di Mattia** and Clare Leavy***, Bio Products Laboratory, UK

*Corresponding author - Tim Sandle, Head of Microbiology and Sterility Assurance, BPL

** Sterility Assurance Specialist, BPL

*** Sterility Assurance Manager, BPL

Corresponding Author: Tim Sandle

Head of Microbiology and Sterility Assurance,

BPL

Dagger Lane,

Elstree,

WD6 3BX UK.

Email: tim.sandle@bpl.co.uk 


\begin{abstract}
Quality Risk Management has been an essential feature relating to the manufacture of pharmaceutical and healthcare products for several decades, and its centrality is embedded in key regulatory documents, such as Annex 1 to EU GMP where risk assessment needs to be part of the overall biocontamination control strategy. While the message for constructing pro-active risk assessment sis clear, where the industry lacks direction is with case studies. This paper presents one risk assessment tool, and one which is perhaps best suited to microbiological assessments of pharmaceutical processes and presents a case study for its application. The tool discussed is Hazard Analysis and Critical Control Points (HACCP) and the application is with assessing microbiological risks and then establishing locations for environmental monitoring. The case study is a sterility testing isolator. The paper first discusses what HACCP is and how it can be applied in general, before demonstrating how HACCP can be deployed as a robust tool for constructing or reviewing an environmental monitoring regime.
\end{abstract}

\title{
Introduction
}

The concept of Hazard Analysis and Critical Control Points (HACCP) methodology is a system that enables the production of safe products, be they pharmaceuticals or health care products and devices or, as with the origins of HACCP, food. HACCP is an example of a risk assessment tool, and the use of risk assessment, especially proactive risk assessment, is encouraged by regulators as part of Quality Risk Management philosophies (as set out in ICH Q9 among other documents issued by regulators like U.S. FDA and the European Medicines Agency).

The premise of HACCP is that through the thorough analysis of production processes, identification of all hazards that are likely to occur in the production establishment, the identification of critical points in the process at which these hazards may be introduced into product and therefore should be controlled, the establishment of critical limits for control at those points, the verification of these prescribed steps, and the methods by which the pharmaceutical or healthcare establishment and the quality departments can monitor how well process control through the HACCP plan is working (1).

While risk assessment is commonly discussed in relation to pharmaceuticals and healthcare, the adoption of risk tools and the execution of risk assessments is variable in terms of scope and with the quality of the risk assessments conducted. This can be the product of the wrong tool being applied (all too often this is a variant of FMEA - Failure Modes and Effects Analysis) or the wrong team being assembled or a failure to carefully map out the process.

Microbiological risk assessments do not always fit well with FMEA, since the approach does not easily permit the process flow to be mapped. Moreover, FMEA has an over-reliance upon detection and detection is used to mitigate the risk (given that the risk is expressed as numerical outcome - a risk priority number). Certainly, there are cases where detection may limit the implementation of effective risk controls or confuse the objective of the assessment (2). Detection should only be introduced once risks have been adequately controlled; this is especially important with microbiology given the limitations of environmental monitoring methods, as succinctly set out by Sutton (3) where the accuracy, precision, sensitivity, and limits of detection of monitoring methods is uncertain, , the variations with culture media types and incubation conditions, and the phenomenon within the environment of viable but non-culturable microorganisms.

Yet monitoring is still necessary, especially when looking for variations in trends. To aid the microbiologist there remains a dearth of case studies. This paper aims to help, in an incremental way, to fill this gap by demonstrating how HACCP can be used to assess an established environmental 
monitoring programme and to form part of the overall biocontamination control strategy. In this case, this is a sterility testing facility (a cleanroom containing two isolators). The HACCP approach helps to consider how materials and personnel enter and leave the cleanroom, and how the sterility test is conducted, in terms of risks and then how the appropriate control points (the environmental monitoring locations) are selected. While the case study is focused on a test common to sterile products manufacturing, the general approach will be of interest to those involved with non-sterile pharmaceutical manufacture as well. Of interest to all readers will be the way HACCP identifies priority hazards and allows establishing targeted control systems, thus putting focus mainly on preventive measures rather than on end-product testing.

Prior to presenting the case study, the paper provides a short history of HACCP and discusses the generalized approach for conducting a HACCP.

\section{Short history of HACCP}

The HACCP approach was developed during the late 1950s through a collaboration of food scientists and engineers working at three centres: The Pillsbury Company, the Natick Research Laboratories, and the National Aeronautics and Space Administration. The group's aim was to design a system to assess the risks associated with food intended for the future manned space programme. The aim was to ensure that quality was built into the process at all stages $(4,5)$.

Later, in 1971, The Pillsbury Company presented the risk-based concept to the National Conference on Food Protection (this was a conference sponsored the Food and Drug Administration (FDA) together with the American Public Health Association). The concept was presented as HACCP, formed of three principles:

- Identification and assessment of hazards associated with food from farm to fork;

- Determination of the critical control points to control any identified hazard; and

- Establishment of a system to monitor the critical control points.

Since then, various changes have been made to the HACCP approach and today, while the underlying philosophy remains the same, there is no 'universal' approach, although all HACCPs are founded on similar principles and stepwise approaches.

HACCP became an increasingly common tool for some food manufacturers in the U.S. to deploy when the FDA incorporated the concepts of HACCP into its low acid and acidified food regulations in 1974, which were a response to various incidents of poisoning resulting from Clostridium botulinum contamination in commercially canned food (6).

However, the use of HACCP did not take off widely during the 1970s; it was only following other instances of food contamination during 1980s that a renewed interest in HACCP occurred and the technique was adopted by several large food processing companies. In 1985, the U.S. National Research Council of the National Academy of Sciences published An Evaluation of the Role of Microbiological Criteria for Foods and Food Ingredients (7). This booklet strongly recommended that the food processing industry and governmental agencies use HACCP.

In terms of standardized approaches, in 1989 The U.S. National Advisory Committee on Microbiological Criteria for Foods (NACMCF) published the first HACCP document issued by a government agency (8). This was followed, in the same year, by the International Commission on Microbiological Specifications for Foods (ICMSF) issuing the publication Microorganisms in Foods 4: 
Application of the Hazard Analysis Critical Control Point (HACCP) System to Ensure Microbiological Safety and Quality (9).

The results of the 1989 are commonly referred to as "The Seven Principles." These principles continue to be used today, and which are: conducting a hazard analysis, determining critical control points (CCP), establishing critical limits, enacting procedures to monitor CCP's, taking corrective action, establishing verification procedures, record keeping and documentation procedures.

\section{HACCP and the pharmaceutical and healthcare sectors: Summary of the literature}

During the 1990s and 2000s the use of HACCP became applied, from the food industry, to parts of the pharmaceutical and healthcare sectors, in a similar way to FMEA (which is common to the engineering sector). This was part of the regulatory drive to embed quality into pharmaceutical production (10). It also reflected changes in thinking by pharmaceutical microbiologists. An HACCP programme shifts the focus of controls toward monitoring in-process preventive control measures. At the same time there is a diminished focus on monitoring the quality of the finished product, reflecting the limitations of many of the methods used for end product testing in terms of reliability (the sterility test being a case in point). Moreover, reliance on end-product testing is particularly inefficient and ineffective when a large sample size and high frequency of sampling is needed to provide statistically reliable data. This also tallied with the importance of assessing and preventing risks during processing, rather than simply hoping that the finished product would pass the end-product test.

There are various examples of HACCP's application, such as assessing patient risks to medication (11); computer systems in GMP environments (12); water generation (13); and medical device manufacture (14). In terms of the application of HACCP to environmental monitoring, there have been few published case studies. A selection of those available, and which may assist the reader in terms of a wider review of the literature, is presented below is descending order:

- Satyada and Sandle (15) "Rationale for the selection of microbial monitoring locations on personnel working in aseptic processing areas". The authors use HACCP principles to assess what personnel do when working in aseptic processing areas in order to select environmental monitoring locations on the cleanroom gown.

- McFarland (16) "Risk-Based Microbial Assessment Tool (R-MAT): A Novel Approach to Assessing Environmental and Critical Utilities Excursions". The author demonstrates how a HACCP-style approach can assist in both determining the appropriate actions for addressing excursions and assist the organization in developing a proactive means of preventing excursions.

- Ziegler et al (17): "Revision of Viable Environmental Monitoring in a Development Pilot Plant Based on Quality Risk Assessment: A Case Study". The authors focused here on assessing the consequence of a high microbial load during the development of pilot plant phase GMP.

- Sandle (18) "Aseptic Transfer Risk Assessment: A Case Study". The author looks at the specific risks associated with transferring items between different grades of cleanrooms.

- Sandle (19) "Current Methods and Approaches for Viral Clearance". The author presents a case study of how HACCP can be used to eliminate viral risks from a pharmaceutical process. 
- Annalaura et al (20) "The application of quality risk management to the bacterial endotoxins test: use of hazard analysis and critical control points." The authors show how HACCP can be used to manage an analytical process (the LAL test) and propose how to conduct the necessary steps to assess test problems.

- Sandle (21) "Risk assessment and monitoring of cleanrooms". The author looks at how the process mapping approach in HACCP can assist with the selecting of environmental monitoring locations

- Sandle (22) “Application of Quality Risk Management To Set Viable Environmental Monitoring Frequencies in Biotechnology Processing and Support Areas". The author uses HACCP-based risk assessment and risk filtering to determine appropriate frequencies for environmental monitoring

- Singer (23) "A Strategy for Developing Robust Pharmaceutical Microbiological Control". The author makes reference to the use of HACCP for environmental monitoring, although no specific examples are given.

- Sandle (24) "Risk Management in Pharmaceutical Microbiology". The author looks at the use of HACCP to create process flows and to detect suitable monitoring sample types and locations.

- Bissett (25) "Developing decontamination strategies and monitoring tools". The author examines decontamination from hand hygiene to sterilization of instruments and discuss how HACCP can be used to monitor and record practice, ensuring that consistent standards are achieved.

- Sutton (3) "The Environmental Monitoring Programme In a GMP Environment". The author discusses HACCP style approaches to orientating environmental monitoring locations to the points of greatest risk.

- Bonan et al (26) "The application of hazard analysis and critical control points and risk management in the preparation of anti-cancer drugs". The authors apply HACCP to the preparation of anti-cancer drugs, with the intention of identifying critical control points in the cancer chemotherapy process and to propose control measures and corrective actions to manage these processes.

- Ashtekar (27) "Microbiological Risk Analysis". This is an example of one of the best book chapters on the HACCP subject and its practical application to environmental monitoring.

- Jahnke and Kuehn (14) "Use of the Hazard Analysis and Critical Control Points (HACCP) risk assessment on a medical device for parenteral application". This builds on Janke's 1997 paper, applying HACCP to a different pharmaceutical process.

- Whyte and Eaton (28) "A cleanroom contamination control system". The authors applying a modification of HACCP to aseptic processing, focusing on contamination transfer metrics.

- Jahnke (29) "Use of the HACCP concept for the risk analysis of pharmaceutical manufacturing process." This was one of the earliest examples of HACCP to provide an overview of a pharmaceutical production process, to determine monitoring points, with a particular focus on quality assurance of hygiene and other parameters influencing the quality of the product. 
- Isoard et al (30) "Biocontamination, European standardization and pharmaceutical industry." The authors, in one of the first uses of HACCP for pharmaceuticals, look at using HACCP to identify biocontamination risks within a pharmaceutical processing area.

This paper, through the presentation of a new case study, helps add to the available literature on the application of HACCP for pharmaceuticals and healthcare in relation to microbiological monitoring

\section{Generalized HACCP methodology}

The objective of HACCP is main aim is to prevent known hazards and to reduce the risks that they will cause at specific points in the product. Hazards are classified as biological, chemical, or physical agents or operations that might cause illness or injury if not controlled (the focus in this paper is with the biological). It is useful to pause here and define the basic elements of 'HACCP':

Hazard: Any circumstance in the production, control and distribution of a pharmaceutical which can cause an adverse health effect.

Hazard Analysis: The process of collecting and evaluating information on hazards which should be addressed in the HACCP plan.

Critical Control Point (CCP): A step at which control can be applied and is essential to prevent or eliminate a pharmaceutical quality hazard or reduce it to an acceptable level

In context of this paper, HACCP is about examining microbial contamination and pinpointing the ways by which microbial contamination can be introduced or perpetuated throughout the process. A separate HACCP will be required for each room or process (where more than one room may be combined), this is because microbial hazards will be specific to each room of the facility and different microbial hazards will arise in relation to each step of the process being evaluated.

There are slight variations on how HACCP is implemented. A general approach to HACCP (based on the Canadian Food Inspection Agency) is (31):

Preliminary tasks:

a. Assemble HACCP team: When using HACCP analysis to determine the sampling locations in an environmental monitoring programme, a thorough knowledge of the process and area is required. For a HACCP team to work effectively, all team members need to understand the application of HACCP principles. For best results, the whole team should be trained using a practical training intervention that covers both theory and application of HACCP.

b. Describe the final product (or process stage of concern): A full description of the product and the process should be drawn up, including relevant quality information such as the composition, physical/chemical properties, temperatures, method of cleaning, process steps and so on.

c. Identify the products intended use,

d. Construct the process flow diagram: a flow chart provides a clear and simple visual representation of involved steps. A chart also facilitates understanding, explaining and systematically analysing complex processes/designs and associated risks.

e. Verify the flow diagram.

Implement the seven principles of HACCP: 
- Implement principle 1. Conduct a hazard analysis, focusing on microbial contamination risks. This is on viable organisms (bacteria and fungi) and their metabolic by-products, as applicable (such as endotoxin hazards in relation to pharmaceutical water systems). Contamination will be a risk in the air, in terms of dispersal, and on surfaces, especially when one object is transferred to another or where a person transfers contamination through touching.

Examples of things to look for include:

1. Personnel flow patterns, especially high traffic areas; changing rooms; airlocks and barriers between cleanrooms of different grades; points where transfer of people or materials happens; and proximity of personnel to critical activities, such as exposed product.

For example, areas adjacent to the cleanroom are likely to be more contaminated than the production cleanroom; the material airlock and personnel change areas will inevitably be contaminated by the activities going on in these areas and the contamination in the outside corridors and service areas may not be as well controlled.

2. Material, equipment, and product flow patterns.

Equipment represent another source. Machines can generate contamination by the movement of their constituent parts or they can function as secondary sources of contamination, from contaminants deposited on them from personnel.

3. Use of a given cleanroom, including processes that are conducted in the room and points of product exposure and transfer.

4. Frequency of cleaning and disinfection.

5. Presence of difficult to clean or disinfect surfaces.

6. Storage of supplies

7. Presence of drains and water sources in a room.

Assess the importance of these sources and if they are / are not hazards that need to be controlled. Examples include:

a) The amount of contamination on, or in, the source that is available for transfer.

b) Ease by which the contamination is dispersed or transferred.

c) The proximity of the source to the critical point where the product is exposed.

d) How easily the contamination can pass through the control method.

- Apply principle 2. Identify the Critical Control Points (CCPs).

A Critical Control Point (CCP) is a point where control can be applied and is assessed as being essential to prevent or eliminate a hazard or, alternatively, to reduce the hazard to an acceptable level. Here it is important to assess if there are sufficient controls in place to prevent (or reduce the likelihood) of the hazard from occurring.

This falls under the area of risk control, which is a decision-making activity designed to reduce and/or accept risks. The fundamental level its purpose is to reduce the risk to an acceptable level. During risk control activities the following key questions should be asked: 
- What can be done to reduce or eliminate risks?

- What is the appropriate balance among benefits, risks and resources?

- Are new risks introduced as a result of the identified risks being controlled?

CCPs represent points in a process where controls should be measured and monitored to ensure risk is not realized. That is, they are invariably the suitable points where environmental monitoring should take place. A point that does not require environmental monitoring is commonly referred to as a 'control point' as opposed to a 'critical control point'. The differences here can be assessed using a decision tree, if required. For example, see figure 1 below:

Figure 1: HACCP decision flow chart

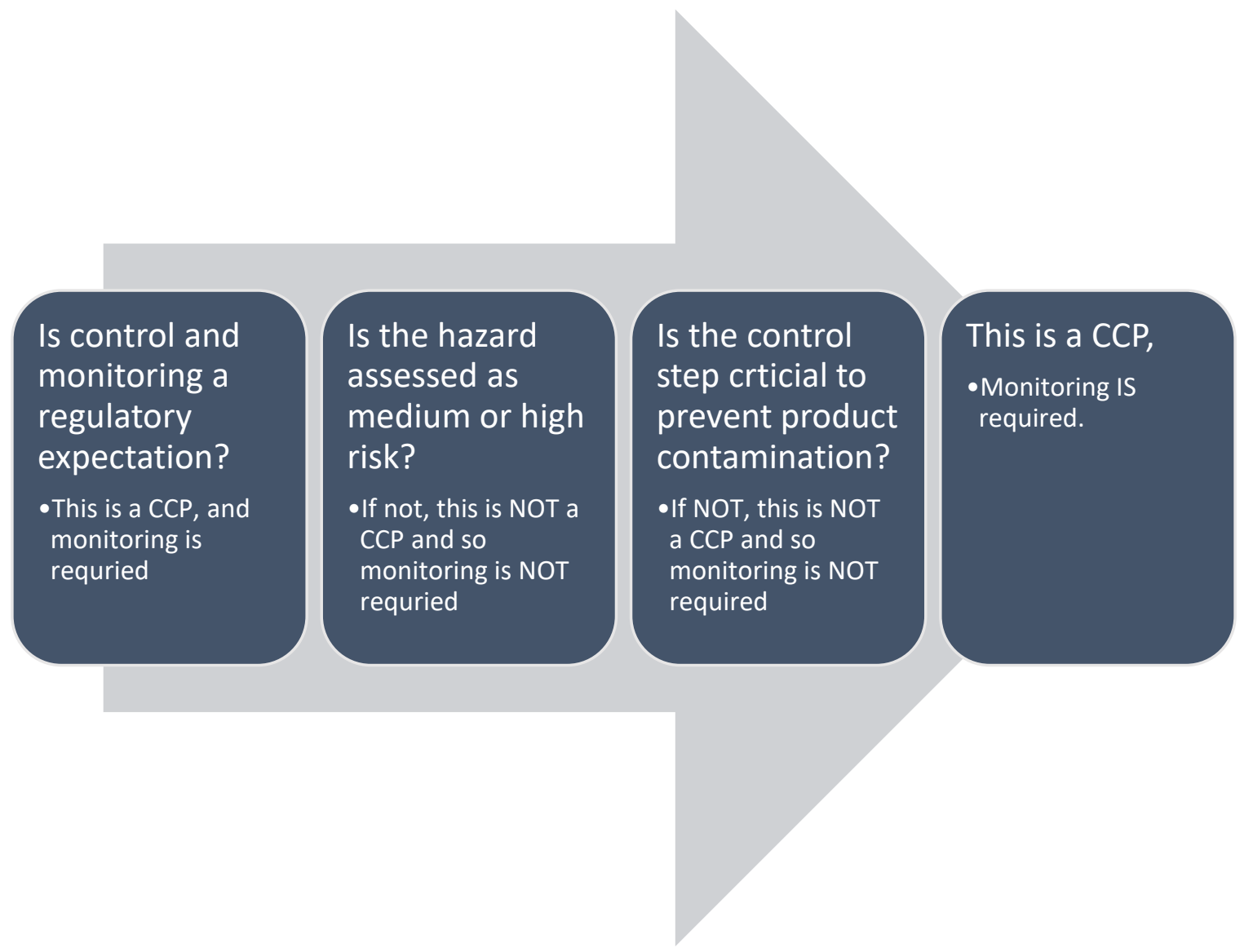

In assessing a CCP, the following can be useful (Whyte and Eaton, 2002):

1. The amount of microbial contamination on, or in, the source in its uncontrolled state and available for transfer (by air or through contact);

2. The ease by which the contamination is dispersed or transferred;

3. The proximity of the source to the critical point where the product is exposed, or important operation is to be performed (like an aseptic activity);

4. How well the contamination is controlled.

- Employ principle 3. Establish critical limits. 
Limits are either based on regulatory action levels or calculated based on a review of historical data.

- Implement principle 4. Establish CCP monitoring procedures.

This principle is about selecting appropriate methods for monitoring. It is also about the environmental monitoring programme as a whole. The programme should be sufficiently robust to detect loss of control at the CCP. For this assessment, the use of trend analysis is important. The frequency of environmental monitoring will vary based on system capabilities and criticality of the control, and hence it may need to be adjusted depending on data patterns. There are other risk tools available to help assess monitoring frequencies.

- Organize principle 5. Establish corrective action.

Specific corrective actions should be developed for each CCP in the environmental monitoring system in order to handle out-of-limits results, or upward trends, from monitoring limits if and when they occur.

- Institute principle 6. Establish verification procedures.

This means reviewing the HACCP regularly to see if it remains fit for purpose. The effectiveness of the environmental monitoring programme should be monitored by trending of resultant data and reassessment of hazards when necessary.

- Principle 7. Establish record keeping procedures.

This means having an SOP in place together with a data capture system, to assess the environmental monitoring data.

Sometimes an eighth principle is added, which is to ensure that personnel are trained and are cognizant in relation to the identified hazards.

\section{Advantages and disadvantages of HACCP}

A key advantage of HACCP is that it uses principles familiar to those working in healthcare and pharmaceuticals and the risk approach often comes across as intuitive for microbiologists. HACCP additionally considers control and monitoring methods as important parts of its system. When it is adapted for use in the pharmaceutical and healthcare industry, the HACCP system offers a systematic way of assessing, controlling, and monitoring microbial risk.

HACCP does have some weaknesses, such as not offering a clear, formal process for characterizing or differentiating the risks posed by a potential hazard (32). A second is that the HACCP requirement to pre-define corrective actions for situations when Critical Control Points (CCP) limits have been exceeded is only effective if the original information going in was correct and that the HACCP has been kept up-to-date.

In considering HACCP in the pharmaceuticals and healthcare domains, there is some further and useful, guidance available from the World Health Organization (33).

Case study: Sterility testing isolators and room 
This section of the paper looks at the application of HACCP as a case study, with the case study being sterility testing. The scope of the HACCP is the passage of materials and personnel into and out of the sterility testing suite (a cleanroom), with personnel entering through a changing room and materials via a transfer port. Also addressed are the preparation of sterility testing loads and the activity of sterility testing. Controls over sterility testing are of importance, given that a false positive with the sterility test is very difficult to prove and hence the consequence is most likely to be batch rejection (34).

The HACCP focuses on:

- Preparation of a load for sterility testing;

- Conducting a membrane filtration sterility test;

- Conducting a direct inoculation sterility test.

This was in relation to two solid wall isolators, attached to a transfer port. The mechanism for decontamination of the isolator was hydrogen peroxide vapor $(35 \% \mathrm{w} / \mathrm{v})$. The isolator was housed within an EU GMP Grade D / ISO 14644 class 8 (at rest) cleanroom.

The photograph (figure 2) below shows the general isolator set-up:

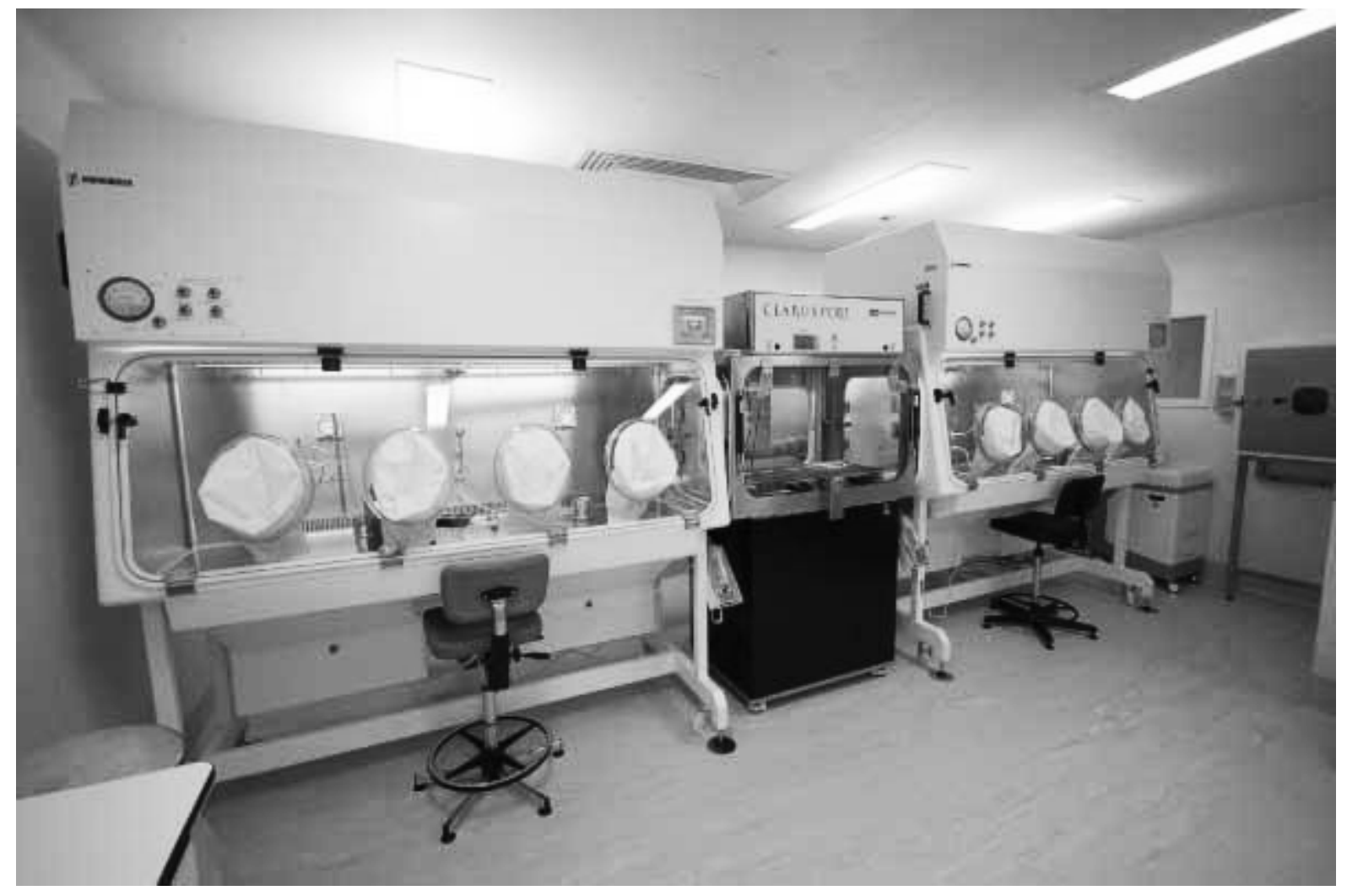

Figure 2: Isolator set-up. There are two testing isolators connected by a gassing chamber. The transfer port is capable of independent decontamination using hydrogen peroxide. In the corner of the room, to the left-hand side, the transfer chamber can be seen.

The photograph (figure 3) below shows the isolator in operation: 


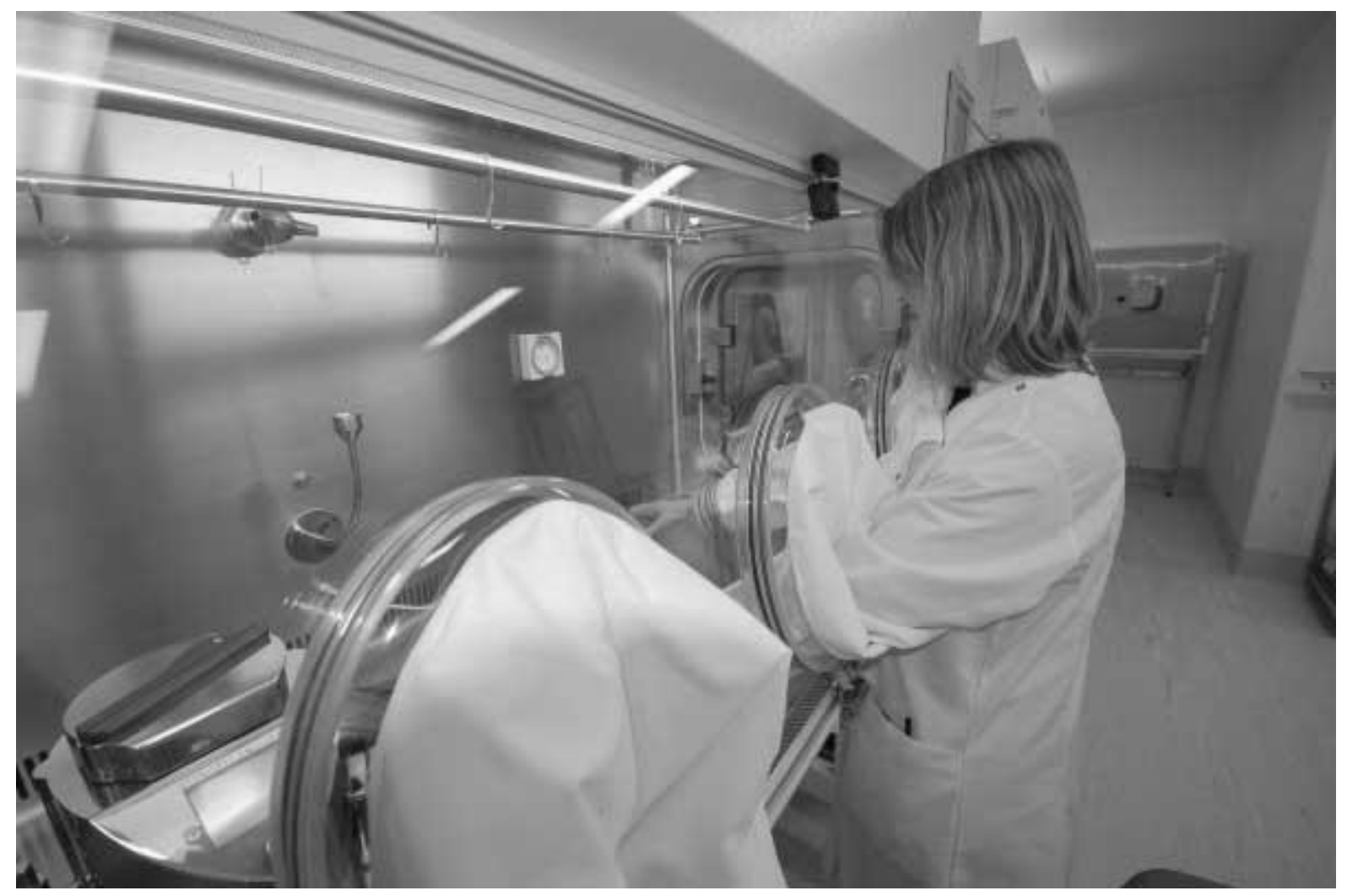

Figure 3: Operator using one of the solid wall isolators for the purpose of sterility testing

The isolators are used for conducting both membrane filtration and direct inoculation sterility tests, according to the United States, European and Japanese pharmacopeias. For the membrane filtration test a sterility test pump is used, together with a cannister system.

The isolators and the room had been operating for three years and a monitoring programme was in place. The monitoring programme had been set up based on professional judgement, but without a formal risk assessment being undertaken to determine the most appropriate locations. The purpose of the HACCP was to review the current locations and to make a reference with regards to their suitability, in relation to contamination control.

The objective of the HACCP was to:

1. Review the microbiological hazards, which could lead to environmental contamination of the room or the isolator environment;

2. Review the microbiological hazards, which could lead to a sterility test failure;

3. Outline any new measures to control the hazards;

4. To review environmental monitoring locations and to make recommendations for either:

a. The removal of locations which do not provide any objective evidence of room or isolator contamination at areas of greatest risk;

b. Addition of new monitoring locations that can provide additional information relating to room or isolator contamination at areas of greatest risk;

5. Assess the frequency of monitoring for current and additional locations;

6. To recommend any appropriate actions should environmental monitoring excursions or upward trends occur. 
In running the HACCP, the following terms were used to assess severity (Table 1):

Table 1: Severity interpretation table

\begin{tabular}{|l|l|}
\hline Severity of hazard & Definition \\
\hline Negligible & Almost no impact \\
\hline Minor & Impact has no impact upon microbial risk \\
\hline Serious & Microorganisms could affect process or product \\
\hline Critical & Product quality will be adversely affected \\
\hline Catastrophic & Direct risk to patient safety \\
\hline
\end{tabular}

And the following was used to assess the likelihood of the hazard occurring Table 2):

Table 2: Likelihood interpretation table

\begin{tabular}{|l|l|}
\hline Expression & Criteria \\
\hline Remote & Improbable likelihood of occurrence \\
\hline Unlikely & Quite unlikely to occur \\
\hline Occasional & Moderate \\
\hline Likely & Failure is likely \\
\hline Frequent & Failure happens on most occasions \\
\hline
\end{tabular}

The HACCP was conducted according to the following stages:

a) Conduct process flow chart.

b) Process step table identifying hazards

c) Selection of monitoring methods, limits, locations and frequencies.

d) Map of current and proposed locations.

e) Actions to be taken in the event of an OOL / risk impact (all locations).

Each of these stages is examined next.

Stage A: $\quad$ Process flow chart

The process flow chart is presented below in figures 4 and 5 : 
Figure 4: Process flow part 1
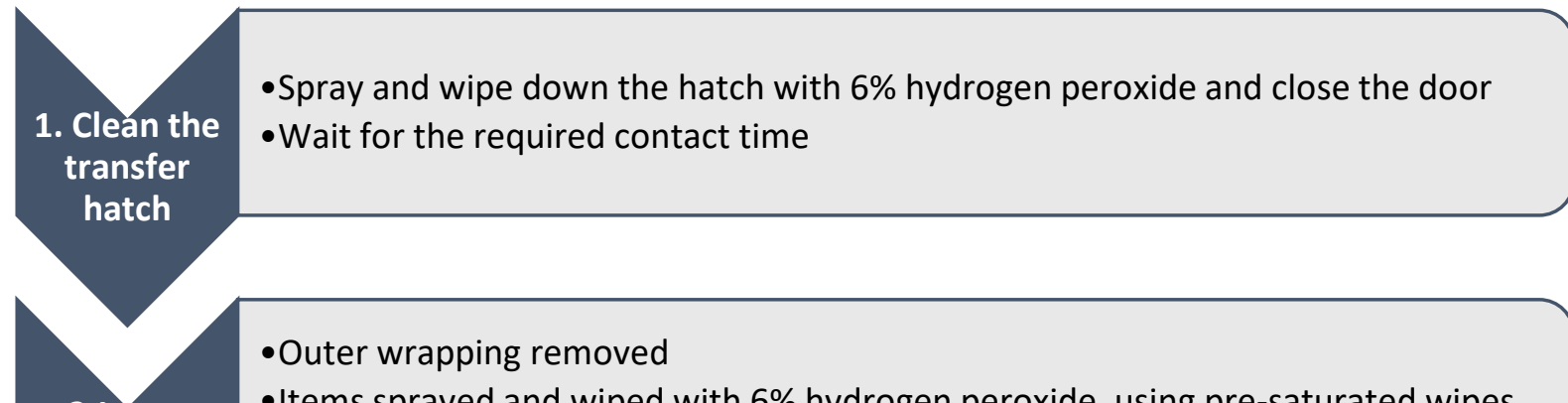

-Outer wrapping removed

2.Items

-Items sprayed and wiped with $6 \%$ hydrogen peroxide, using pre-saturated wipes.

placed in

-Wait for the required contact time.

hatch

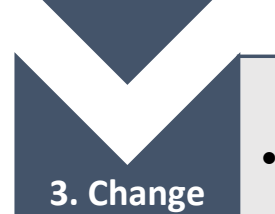

-Person goes through changing room and dons isolator coat and PPE

procedure

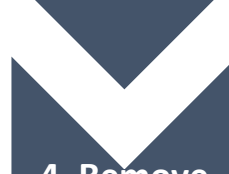

-After contact time has elapsed, remove items.

4. Remove

-Place items on the bench

hatch

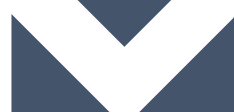

-Sanitise gloves with 70\% IPA

5. Begin

-Inspect and label culture media bottles

assembling

-Wipe product and media with $6 \%$ hydrogen peroxide, using pre-saturated wipes

load

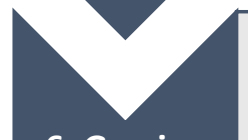

- Run empty port cycle before satinising any loads

6. Gassing

chamber

-All items should be loaded onto appropiate racking

-Items are sanitised in the gassing chamber 
Figure 5: Process flow part 2

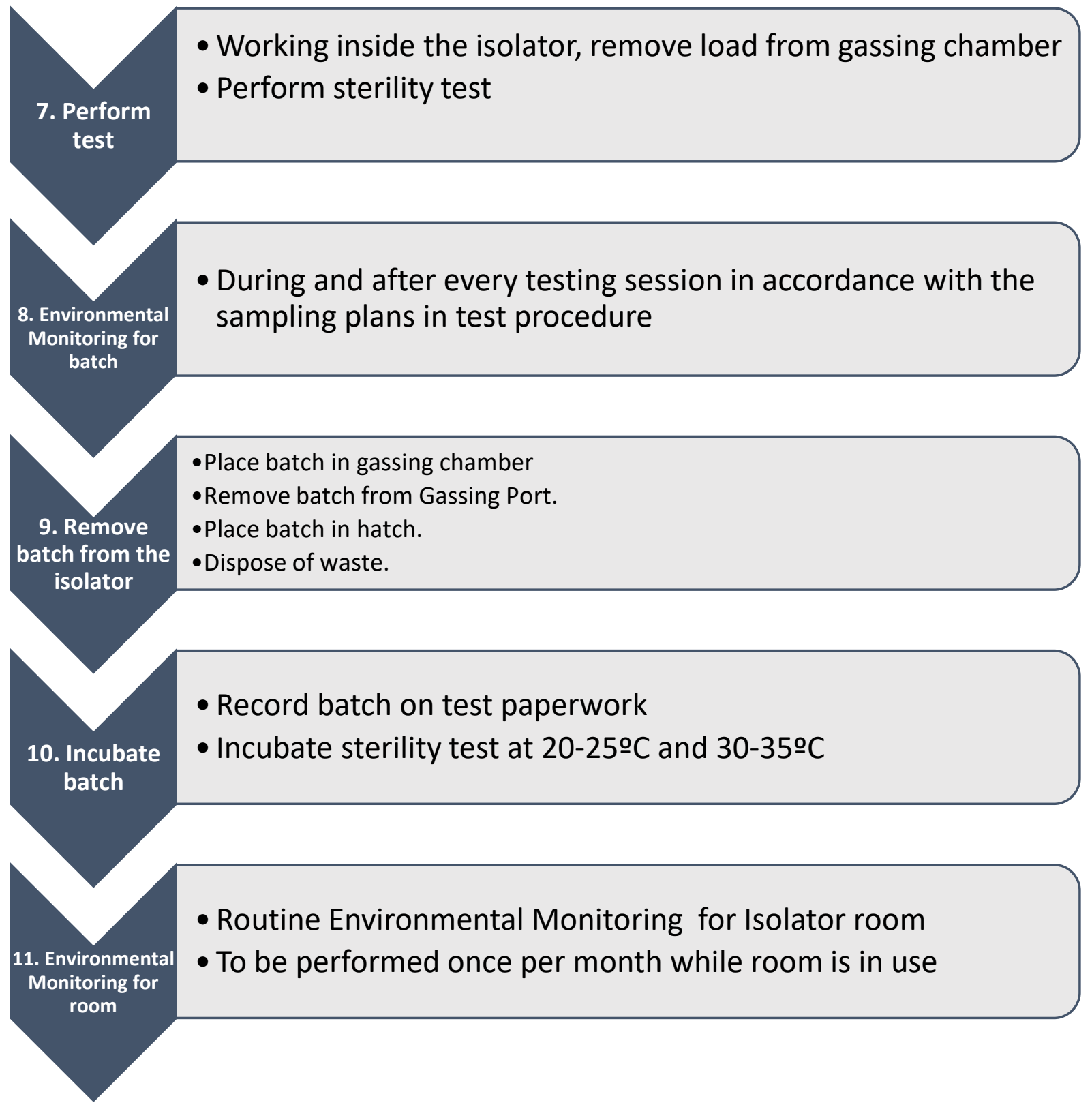


Stage B: Table 3: Process step table identifying hazards

The Table (Table 3) below looks at each step in the process, in e relation hazards and the identification of CCPs.

\begin{tabular}{|c|c|c|c|c|c|c|c|c|}
\hline $\begin{array}{l}\text { Process } \\
\text { step }\end{array}$ & Hazard & $\begin{array}{l}\text { Sever } \\
\text { ity of } \\
\text { hazar } \\
\text { d }\end{array}$ & $\begin{array}{l}1 . \\
\text { Preven } \\
\text { tive } \\
\text { measur } \\
\text { es for } \\
\text { the } \\
\text { hazard }\end{array}$ & $\begin{array}{l}\text { 2. } \\
\text { Does } \\
\text { the } \\
\text { step } \\
\text { reduce } \\
\text { the } \\
\text { likelih } \\
\text { ood of } \\
\text { the } \\
\text { hazard } \\
\text { to an } \\
\text { accept } \\
\text { able } \\
\text { level? }\end{array}$ & $\begin{array}{l}\text { 3. } \\
\text { Could } \\
\text { microbi } \\
\text { al } \\
\text { contami } \\
\text { nation } \\
\text { with the } \\
\text { hazard } \\
\text { exceed } \\
\text { accepta } \\
\text { ble } \\
\text { levels? }\end{array}$ & $\begin{array}{l}4 . \\
\text { Will a } \\
\text { subseque } \\
\text { nt } \\
\text { process } \\
\text { step } \\
\text { eliminate } \\
\text { the } \\
\text { hazard or } \\
\text { reduce it } \\
\text { to an } \\
\text { acceptabl } \\
\text { e level? }\end{array}$ & $\begin{array}{l}5 . \\
\text { Monitori } \\
\text { ng } \\
\text { required } \\
\text { (a CCP) }\end{array}$ & $\begin{array}{l}6 . \\
\text { Frequen } \\
\text { cy of } \\
\text { monitori } \\
\text { ng }\end{array}$ \\
\hline $\begin{array}{l}1 \\
\text { Disinfec } \\
\mathbf{t} \\
\text { transfer } \\
\text { hatch }\end{array}$ & $\begin{array}{l}\text { Transfer } \\
\text { ring } \\
\text { contami } \\
\text { nation } \\
\text { from an } \\
\text { unclassif } \\
\text { ied area } \\
\text { to a } \\
\text { Grade D } \\
\text { room }\end{array}$ & $\begin{array}{l}\text { Serio } \\
\text { us }\end{array}$ & $\begin{array}{l}\text { Yes, } \\
\text { wipe } \\
\text { down } \\
\text { hatch } \\
\text { with } 6 \% \\
\text { hydroge } \\
\mathrm{n} \\
\text { peroxid } \\
\text { e and } \\
\text { wait for } \\
\text { the } \\
\text { required } \\
\text { contact } \\
\text { time }\end{array}$ & $\begin{array}{l}\text { Yes- } \\
\text { remov } \\
\text { al of } \\
\text { outer } \\
\text { wrappi } \\
\text { ng and } \\
\text { disinfe } \\
\text { ction. } \\
\text { Howev } \\
\text { er, no } \\
\text { airlock } \\
\text { betwe } \\
\text { en } \\
\text { unclass } \\
\text { ified } \\
\text { area } \\
\text { and } \\
\text { grade } \\
\text { D } \\
\text { room; } \\
\text { and a } \\
\text { manua } \\
\text { I proces } \\
\text { s. }\end{array}$ & Yes & $\begin{array}{l}\text { Yes - } \\
\text { items } \\
\text { disinfecte } \\
d \quad \text { on } \\
\text { transfer } \\
\text { into } \\
\text { isolator } \\
\text { and } \\
\text { isolator } \\
\text { bio- } \\
\text { deconta } \\
\text { mination } \\
\text { cycle run. } \\
\text { However, } \\
\text { there is a } \\
\text { risk of } \\
\text { spore } \\
\text { transfer. }\end{array}$ & $\begin{array}{l}\text { Yes, } \\
\text { however } \\
\text { process } \\
\text { step ' } 4 \text { ' } \\
\text { below is a } \\
\text { greater } \\
\text { challenge } \\
\text { since this } \\
\text { is a post- } \\
\text { activity } \\
\text { assessmen } \\
\text { t. }\end{array}$ & N/A \\
\hline $\begin{array}{l}2 \text { Items } \\
\text { placed } \\
\text { in hatch }\end{array}$ & $\begin{array}{l}\text { Transfer } \\
\text { ring } \\
\text { contami } \\
\text { nation } \\
\text { from an } \\
\text { unclassif } \\
\text { ied area }\end{array}$ & $\begin{array}{l}\text { Serio } \\
\text { us }\end{array}$ & $\begin{array}{l}\text { Yes, } \\
\text { Items } \\
\text { sprayed } \\
\text { and } \\
\text { wiped } \\
\text { with 6\% } \\
\text { hydroge }\end{array}$ & $\begin{array}{l}\text { No, no } \\
\text { airlock } \\
\text { betwe } \\
\text { en } \\
\text { unclass } \\
\text { ified } \\
\text { area }\end{array}$ & Yes & No & $\begin{array}{l}\text { Yes, } \\
\text { however it } \\
\text { would be } \\
\text { inappropri } \\
\text { ate to } \\
\text { have agar } \\
\text { residues }\end{array}$ & N/A \\
\hline
\end{tabular}




\begin{tabular}{|c|c|c|c|c|c|c|c|c|}
\hline & $\begin{array}{ll}\text { to } & \text { a } \\
\text { Grade } & D \\
\text { room } & \end{array}$ & & $\begin{array}{l}\mathrm{n} \\
\text { peroxid } \\
\mathrm{e}\end{array}$ & $\begin{array}{l}\text { and } \\
\text { grade } \\
\text { D room }\end{array}$ & & & $\begin{array}{l}\text { on items } \\
\text { to be } \\
\text { placed } \\
\text { into the } \\
\text { cleanroom } \\
\text { A study } \\
\text { has } \\
\text { previously } \\
\text { been } \\
\text { conducted } \\
\text {. }\end{array}$ & \\
\hline $\begin{array}{l}3 \\
\text { Change } \\
\text { procedu } \\
\text { re }\end{array}$ & $\begin{array}{l}\text { Transfer } \\
\text { ring } \\
\text { contami } \\
\text { nation } \\
\text { from an } \\
\text { unclassif } \\
\text { ied area } \\
\text { to a } \\
\text { Grade D } \\
\text { room }\end{array}$ & $\begin{array}{l}\text { Serio } \\
\text { us }\end{array}$ & $\begin{array}{l}\text { Yes, } \\
\text { person } \\
\text { goes } \\
\text { through } \\
\text { changin } \\
\mathrm{g} \text { room } \\
\text { and } \\
\text { wears } \\
\text { isolator } \\
\text { coat and } \\
\text { PPE }\end{array}$ & $\begin{array}{l}\text { Yes, no } \\
\text { outsid } \\
\text { e } \\
\text { clothes } \\
\text { in } \\
\text { contac } \\
t \text { with } \\
\text { produc } \\
\text { t. }\end{array}$ & N/A & N/A & $\begin{array}{l}\text { Changing } \\
\text { room is } \\
\text { monitored } \\
\text { when the } \\
\text { isolator } \\
\text { room is in } \\
\text { use. }\end{array}$ & $\begin{array}{l}\text { Once per } \\
\text { month, } \\
\text { to assess } \\
\text { overall } \\
\text { control }\end{array}$ \\
\hline $\begin{array}{l}4 \\
\text { Remove } \\
\text { items } \\
\text { from } \\
\text { hatch }\end{array}$ & $\begin{array}{l}\text { Transfer } \\
\text { ring } \\
\text { contami } \\
\text { nation } \\
\text { from an } \\
\text { unclassif } \\
\text { ied area } \\
\text { to a } \\
\text { Grade D } \\
\text { room }\end{array}$ & $\begin{array}{l}\text { Serio } \\
\text { us }\end{array}$ & $\begin{array}{l}\text { Yes, } \\
\text { items } \\
\text { sprayed } \\
\text { with } 6 \% \\
\text { hydroge } \\
\mathrm{n} \\
\text { peroxid } \\
\text { e and } \\
\text { wait for } \\
20 \\
\text { minutes } \\
\text { contact } \\
\text { time }\end{array}$ & $\begin{array}{l}\text { No, no } \\
\text { airlock } \\
\text { betwe } \\
\text { en } \\
\text { unclass } \\
\text { ified } \\
\text { area } \\
\text { and } \\
\text { grade } \\
\text { D room }\end{array}$ & Yes & $\begin{array}{l}\text { Yes - } \\
\text { items } \\
\text { disinfecte } \\
d \quad \text { on } \\
\text { transfer } \\
\text { into } \\
\text { isolator } \\
\text { and } \\
\text { isolator } \\
\text { bio- } \\
\text { deconta } \\
\text { mination } \\
\text { cycle run. } \\
\text { However, } \\
\text { there is a } \\
\text { risk of } \\
\text { spore } \\
\text { transfer. }\end{array}$ & $\begin{array}{l}\text { Contact } \\
\text { plate } \\
\text { taken of } \\
\text { hatch } \\
\text { surface } \\
\text { immediat } \\
\text { ely } \\
\text { following } \\
\text { unloading. } \\
\text { This is a } \\
\text { surface } \\
\text { disinfectio } \\
\mathrm{n} \\
\text { effectivity } \\
\text { check. } \\
\text { Location } \\
\text { in } \\
\text { approxima } \\
\text { te centre. }\end{array}$ & $\begin{array}{l}\text { Per } \\
\text { batch. }\end{array}$ \\
\hline $\begin{array}{l}5 \text { Begin } \\
\text { assembl } \\
\text { ing load }\end{array}$ & $\begin{array}{l}\text { Surface } \\
\text { areas } \\
\text { not } \\
\text { exposed } \\
\text { to the } \\
\text { hydroge } \\
\text { n } \\
\text { peroxide }\end{array}$ & $\begin{array}{l}\text { Serio } \\
\text { us }\end{array}$ & $\begin{array}{l}\text { Yes, } \\
\text { wipe } \\
\text { media } \\
\text { and } \\
\text { product } \\
\text { with } 6 \% \\
\text { hydroge } \\
\text { n } \\
\text { peroxid } \\
\text { e }\end{array}$ & $\begin{array}{l}\text { Yes, } \\
\text { disinfe } \\
\text { ctant } \\
\text { applie } \\
d \text { to } \\
\text { less } \\
\text { expose } \\
\text { d } \\
\text { surface } \\
\text { s }\end{array}$ & $\begin{array}{l}\text { Unlikely, } \\
\text { due to } \\
\text { previous } \\
\text { control } \\
\text { steps. }\end{array}$ & $\begin{array}{l}\text { Yes - bio- } \\
\text { deconta } \\
\text { mination } \\
\text { cycle run }\end{array}$ & $\mathrm{N} / \mathrm{A}$ & N/A \\
\hline
\end{tabular}




\begin{tabular}{|c|c|c|c|c|c|c|c|c|}
\hline $\begin{array}{l}6 \\
\text { Gassing } \\
\text { Port }\end{array}$ & $\begin{array}{l}\text { Cycle } \\
\text { failure }\end{array}$ & $\begin{array}{l}\text { Critic } \\
\text { al }\end{array}$ & $\begin{array}{l}\text { Yes, } \\
\text { alarm } \\
\text { will be } \\
\text { triggere } \\
\text { d }\end{array}$ & $\begin{array}{l}\text { Yes, } \\
\text { oOS } \\
\text { must } \\
\text { be } \\
\text { raised, } \\
\text { and } \\
\text { cycle } \\
\text { repeat } \\
\text { ed }\end{array}$ & $\mathrm{N} / \mathrm{A}$ & N/A & $\mathrm{N} / \mathrm{A}$ & $\begin{array}{l}\text { Physical } \\
\text { paramet } \\
\text { ers } \\
\text { assessed } \\
\text { per } \\
\text { batch. }\end{array}$ \\
\hline \multirow[t]{2}{*}{$\begin{array}{l}7 \\
\text { Environ } \\
\text { mental } \\
\text { monitor } \\
\text { ing } \\
\text { during } \\
\text { batch } \\
\text { testing }\end{array}$} & $\begin{array}{l}\text { Membra } \\
\text { ne } \\
\text { filtration } \\
: \\
\text { microor } \\
\text { ganism } \\
\text { introduc } \\
\text { ed in the } \\
\text { product }\end{array}$ & $\begin{array}{l}\text { Critic } \\
\text { al }\end{array}$ & $\begin{array}{l}\text { No, test } \\
\text { perform } \\
\text { ed } \\
\text { inside } \\
\text { isolator } \\
\text { and } \\
\text { environ } \\
\text { mental } \\
\text { monitori } \\
\text { ng } \\
\text { perform } \\
\text { ed } \\
\text { during } \\
\text { every } \\
\text { testing } \\
\text { session. }\end{array}$ & $\begin{array}{l}\text { No, } \\
\text { sample } \\
\mathrm{s} \text { are } \\
\text { taken } \\
\text { from } \\
\text { critical } \\
\text { areas: } \\
\text { Air- } \\
\text { sample } \\
\mathrm{s} \text { are } \\
\text { during } \\
\text { the } \\
\text { test: } \\
\text { active } \\
\text { air and } \\
\text { settle } \\
\text { plates } \\
\text { - } \\
\text { current } \\
\text { locatio } \\
\text { ns } \\
\text { satisfa } \\
\text { ctory. }\end{array}$ & Yes & No & $\begin{array}{l}\text { Yes, as per } \\
\text { current } \\
\text { plans. }\end{array}$ & $\begin{array}{l}\text { Per } \\
\text { batch. }\end{array}$ \\
\hline & $\begin{array}{l}\text { Direct } \\
\text { inoculati } \\
\text { on: } \\
\text { Microor } \\
\text { ganism } \\
\text { introduc } \\
\text { ed in the } \\
\text { product }\end{array}$ & $\begin{array}{l}\text { Critic } \\
\text { al }\end{array}$ & $\begin{array}{l}\text { No, test } \\
\text { perform } \\
\text { ed } \\
\text { inside } \\
\text { isolator } \\
\text { and } \\
\text { environ } \\
\text { mental } \\
\text { monitori } \\
\text { ng } \\
\text { perform } \\
\text { ed } \\
\text { during } \\
\text { and } \\
\text { after } \\
\text { every } \\
\text { testing } \\
\text { session. }\end{array}$ & $\begin{array}{l}\text { No, } \\
\text { sample } \\
\mathrm{s} \text { are } \\
\text { taken } \\
\text { from } \\
\text { critical } \\
\text { areas: } \\
\text { Air- } \\
\text { sample } \\
\mathrm{s} \text { are } \\
\text { during } \\
\text { the } \\
\text { test: } \\
\text { active } \\
\text { air and } \\
\text { settle } \\
\text { plates } \\
\text { - }\end{array}$ & Yes & No & $\begin{array}{l}\text { Yes, as per } \\
\text { current } \\
\text { plans. }\end{array}$ & $\begin{array}{l}\text { Per } \\
\text { batch. }\end{array}$ \\
\hline
\end{tabular}




\begin{tabular}{|c|c|c|c|c|c|c|c|c|}
\hline & & & & $\begin{array}{l}\text { current } \\
\text { locatio } \\
\text { ns } \\
\text { satisfa } \\
\text { ctory. }\end{array}$ & & & & \\
\hline $\begin{array}{l}8 \\
\text { Environ } \\
\text { mental } \\
\text { monitor } \\
\text { ing post- } \\
\text { batch } \\
\text { testing }\end{array}$ & $\begin{array}{l}\text { Membra } \\
\text { ne } \\
\text { filtration } \\
\text { : EM not } \\
\text { perform } \\
\text { ed on } \\
\text { critical } \\
\text { areas }\end{array}$ & $\begin{array}{l}\text { Serio } \\
\text { us }\end{array}$ & $\begin{array}{l}\text { Yes, } \\
\text { environ } \\
\text { mental } \\
\text { monitori } \\
\text { ng } \\
\text { perform } \\
\text { ed } \\
\text { accordin } \\
\text { g to } \\
\text { plans }\end{array}$ & 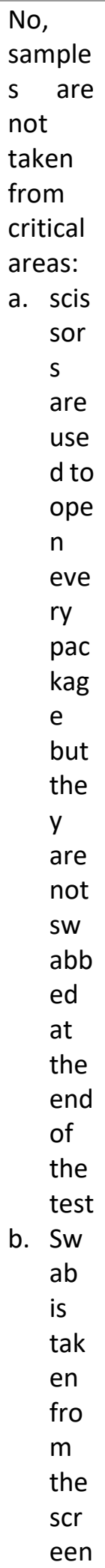 & Yes & No & $\begin{array}{l}\text { a. Take a } \\
\text { swab } \\
\text { for } \\
\text { scissor } \\
\text { s } \\
\text { b. Chang } \\
\text { e swab } \\
\text { taken } \\
\text { from } \\
\text { the } \\
\text { screen } \\
\text { to the } \\
\text { button } \\
\text { which } \\
\text { is used } \\
\text { to stop } \\
\text { and } \\
\text { start } \\
\text { sterilit } \\
\text { y test } \\
\text { pump }\end{array}$ & $\begin{array}{l}\text { Per } \\
\text { batch }\end{array}$ \\
\hline
\end{tabular}




\begin{tabular}{|c|c|c|c|c|c|c|c|c|}
\hline & & & & $\begin{array}{l}\text { of } \\
\text { ste } \\
\text { rilit } \\
\mathrm{y} \\
\text { test } \\
\mathrm{pu} \\
\mathrm{mp} \\
\text { whi } \\
\mathrm{ch} \\
\text { is } \\
\text { not } \\
\text { pre } \\
\text { sse } \\
\mathrm{d} \\
\text { or } \\
\text { tou } \\
\text { che } \\
\mathrm{d} \\
\text { dur } \\
\text { ing } \\
\text { the } \\
\text { test }\end{array}$ & & & & \\
\hline & $\begin{array}{l}\text { Direct } \\
\text { inoculati } \\
\text { on: EM } \\
\text { not } \\
\text { perform } \\
\text { ed on } \\
\text { critical } \\
\text { areas }\end{array}$ & $\begin{array}{l}\text { Serio } \\
\text { us }\end{array}$ & $\begin{array}{l}\text { Yes, EM } \\
\text { perform } \\
\text { ed } \\
\text { accordin } \\
\text { g to } \\
\text { plans }\end{array}$ & $\begin{array}{l}\text { No, } \\
\text { sample } \\
\mathrm{s} \text { are } \\
\text { not } \\
\text { taken } \\
\text { from } \\
\text { critical } \\
\text { areas: } \\
\text { scissor } \\
\mathrm{s} \text { are } \\
\text { used to } \\
\text { open } \\
\text { every } \\
\text { packag } \\
\mathrm{e} \text { but } \\
\text { they } \\
\text { are not } \\
\text { swabb } \\
\text { ed at } \\
\text { the } \\
\text { end of } \\
\text { the } \\
\text { test }\end{array}$ & Yes & No & $\begin{array}{l}\text { Take a } \\
\text { swab for } \\
\text { scissor }\end{array}$ & Per batch \\
\hline $\begin{array}{l}9 \\
\text { Remove } \\
\text { batch } \\
\text { from the } \\
\text { isolator }\end{array}$ & $\begin{array}{l}\text { No } \\
\text { hazard: } \\
\text { product } \\
\text { has been } \\
\text { tested } \\
\text { and EM }\end{array}$ & $\begin{array}{l}\text { Negli } \\
\text { gible }\end{array}$ & $\mathrm{N} / \mathrm{A}$ & $\mathrm{N} / \mathrm{A}$ & N/A & $\mathrm{N} / \mathrm{A}$ & $\mathrm{N} / \mathrm{A}$ & N/A \\
\hline
\end{tabular}




\begin{tabular}{|c|c|c|c|c|c|c|c|c|}
\hline & $\begin{array}{l}\text { complet } \\
\text { ed }\end{array}$ & & & & & & & \\
\hline $\begin{array}{l}10 \\
\text { Incubat } \\
\text { e batch }\end{array}$ & $\begin{array}{l}\text { No } \\
\text { hazard: } \\
\text { product } \\
\text { is being } \\
\text { transferr } \\
\text { ed from } \\
\text { a grade } \\
\text { D room } \\
\text { to } \\
\text { unclassif } \\
\text { ied area }\end{array}$ & $\begin{array}{l}\text { Negli } \\
\text { gible }\end{array}$ & N/A & N/A & N/A & N/A & $\mathrm{N} / \mathrm{A}$ & N/A \\
\hline $\begin{array}{l}11 \\
\text { Environ } \\
\text { mental } \\
\text { Monitor } \\
\text { ing for } \\
\text { isolator } \\
\text { room }\end{array}$ & $\begin{array}{l}\text { EM not } \\
\text { follow } \\
\text { work } \\
\text { flow }\end{array}$ & $\begin{array}{l}\text { Serio } \\
\text { us }\end{array}$ & $\begin{array}{l}\text { Yes, EM } \\
\text { perform } \\
\text { ed } \\
\text { accordin } \\
\mathrm{g} \text { to } \\
\text { plans }\end{array}$ & $\begin{array}{l}\text { No, } \\
\text { sample } \\
\text { s do } \\
\text { not } \\
\text { follow } \\
\text { work } \\
\text { flow }\end{array}$ & Yes & No & $\begin{array}{l}\text { Yes, as } \\
\text { current } \\
\text { plan with } \\
\text { the } \\
\text { following } \\
\text { modificati } \\
\text { ons: } \\
\text { a. Remov } \\
\text { e } \\
\text { existin } \\
\text { g EM } \\
\text { locatio } \\
n \\
\text { coded } \\
\text { SP4 as } \\
\text { it is } \\
\text { taken } \\
\text { from } \\
\text { floor } \\
\text { height. } \\
\text { It is } \\
\text { not } \\
\text { repres } \\
\text { entativ } \\
\text { e of } \\
\text { biobur } \\
\text { den in } \\
\text { the } \\
\text { area } \\
\text { b. Take a } \\
\text { contac } \\
\mathrm{t} \text { plate } \\
\text { on the } \\
\text { floor } \\
\text { by } \\
\text { Gassin } \\
\mathrm{g} \text { Port }\end{array}$ & $\begin{array}{l}\text { Once } \\
\text { per } \\
\text { mont } \\
\mathrm{h} \\
\text { durin } \\
\mathrm{g} \quad \text { a } \\
\text { batch } \\
\text { prepa } \\
\text { ratio } \\
\mathrm{n} . \\
\text { This } \\
\text { prese } \\
\text { nts a } \\
\text { great } \\
\text { er } \\
\text { risk } \\
\text { to the } \\
\text { prod } \\
\text { uct } \\
\text { being } \\
\text { prepa } \\
\text { red } \\
\text { than } \\
\text { durin } \\
\text { g } \\
\text { testin } \\
\text { g. }\end{array}$ \\
\hline
\end{tabular}




\begin{tabular}{|c|c|c|c|c|c|c|c|c|}
\hline & & & & & & & $\begin{array}{l}\text { c. Take a } \\
\text { swab } \\
\text { on } \\
\text { Gassin } \\
\text { g Port } \\
\text { handle } \\
\text { d. Take a } \\
\text { swab } \\
\text { on } \\
\text { door } \\
\text { handle }\end{array}$ & \\
\hline $\begin{array}{l}12 \\
\text { Particle } \\
\text { countin } \\
\mathrm{g} \text { in } \\
\text { Grade A } \\
\text { zone }\end{array}$ & $\begin{array}{l}\text { Particle } \\
\text { build-up } \\
\text { in } \\
\text { isolator }\end{array}$ & $\begin{array}{l}\text { Serio } \\
\text { us }\end{array}$ & $\begin{array}{l}\text { Grade A } \\
\text { airflow } \\
\text { through } \\
\text { HEPA } \\
\text { filters }\end{array}$ & $\begin{array}{l}\text { Yes, } \\
\text { approp } \\
\text { riate } \\
\text { HVAC } \\
\text { design }\end{array}$ & Unlikely & No & $\begin{array}{l}\text { Grade A } \\
\text { air supply } \\
\text { assessed } \\
\text { continuou } \\
\text { sly and } \\
\text { reviewed } \\
\text { weekly. } \\
\text { Particle } \\
\text { counts not } \\
\text { assessed } \\
\text { during } \\
\text { sterility } \\
\text { test. }\end{array}$ & $\begin{array}{l}\text { Conti } \\
\text { nuou } \\
\mathrm{s}\end{array}$ \\
\hline $\begin{array}{l}13 \\
\text { Particle } \\
\text { countin } \\
\mathrm{g} \quad \text { in } \\
\text { isolator } \\
\text { room }\end{array}$ & $\begin{array}{l}\text { Particle } \\
\text { build-up } \\
\text { in room }\end{array}$ & $\begin{array}{l}\text { Serio } \\
\text { us }\end{array}$ & $\begin{array}{l}\text { Correct } \\
\text { airflow } \\
\text { through } \\
\text { HEPA } \\
\text { filters }\end{array}$ & $\begin{array}{l}\text { Yes, } \\
\text { approp } \\
\text { riate } \\
\text { HVAC } \\
\text { design }\end{array}$ & Unlikely & No & $\begin{array}{l}\text { Yes, } \\
\text { particle } \\
\text { counts to } \\
\text { verify } \\
\text { room } \\
\text { conditions }\end{array}$ & $\begin{array}{l}\text { Mont } \\
\text { hly } \\
\text { moni } \\
\text { torin } \\
\text { g } \\
\text { allow } \\
\text { s for } \\
\text { appr } \\
\text { opria } \\
\text { te } \\
\text { trend } \\
\text { asses } \\
\text { smen } \\
\text { t. }\end{array}$ \\
\hline
\end{tabular}

Key:

$\mathrm{EM}=$ Environmental monitoring

HVAC = Heating, ventilation and air conditioning

HEPA $=$ High efficiency particulate air

$\mathrm{PPE}=$ Personal protective equipment

$\mathrm{SP} \quad=\quad$ Settle plate 
Stage C: Table 4: Selection of monitoring methods, limits, locations and frequencies

The table (Table 4) below details the recommended change to the current environmental monitoring sampling plan.

\begin{tabular}{|c|c|c|c|c|c|}
\hline $\begin{array}{lr}\text { Process } & \text { step } \\
\text { and } & \text { CCP } \\
\text { identifier } & \end{array}$ & $\begin{array}{l}\text { Monitoring } \\
\text { limit (CFU or } \\
\text { particle } \\
\text { count) }\end{array}$ & $\begin{array}{l}\text { Monitoring } \\
\text { method }\end{array}$ & $\begin{array}{l}\text { Location for } \\
\text { monitoring }\end{array}$ & $\begin{array}{l}\text { Responsibility } \\
\text { for monitoring }\end{array}$ & $\begin{array}{l}\text { Frequency of } \\
\text { monitoring }\end{array}$ \\
\hline $\begin{array}{l}1 \text { Clean hatch } \\
2 \text { Items placed } \\
\text { in hatch } \\
4 \text { Remove items } \\
\text { from hatch }\end{array}$ & $\begin{array}{l}\text { Action Limit: } \\
50 \\
\text { CFU } / 25 \mathrm{~cm}^{2} \\
\text { (Current alert } \\
\text { level } \\
\text { adopted) }\end{array}$ & Contact plate & Hatch & $\begin{array}{l}\text { Technician who } \\
\text { is loading hatch }\end{array}$ & $\begin{array}{l}\text { Every time a } \\
\text { batch is } \\
\text { loaded in the } \\
\text { hatch }\end{array}$ \\
\hline $\begin{array}{l}\text { Membrane } \\
\text { filtration test: } \\
7 \\
\text { Environmental } \\
\text { monitoring } \\
\text { during batch } \\
\text { testing }\end{array}$ & $\begin{array}{l}\text { Action limit: } \\
1 \mathrm{CFU} / \mathrm{swab} \\
\text { (Current alert } \\
\text { level } \\
\text { adopted) }\end{array}$ & Swab & $\begin{array}{l}\text { SW02: } \\
\text { Sterility test } \\
\text { pump button } \\
\text { SW07: } \\
\text { scissors }\end{array}$ & $\begin{array}{l}\text { Technician who } \\
\text { is performing } \\
\text { the test }\end{array}$ & $\begin{array}{l}\text { Every batch } \\
\text { tested by this } \\
\text { method }\end{array}$ \\
\hline $\begin{array}{l}8 \\
\text { Environmental } \\
\text { monitoring } \\
\text { post- batch } \\
\text { testing }\end{array}$ & & & & & \\
\hline $\begin{array}{l}\text { Direct } \\
\text { inoculation } \\
\text { test: } \\
7 \\
\text { Environmental } \\
\text { monitoring } \\
\text { during batch } \\
\text { testing } \\
8 \\
\text { Environmental } \\
\text { monitoring } \\
\text { post- batch } \\
\text { testing }\end{array}$ & $\begin{array}{l}\text { Action limit: } \\
1 \mathrm{CFU} / \mathrm{swab} \\
\text { (Current alert } \\
\text { level } \\
\text { adopted) }\end{array}$ & Swab & $\begin{array}{l}\text { SW03: } \\
\text { scissors }\end{array}$ & $\begin{array}{l}\text { Technician who } \\
\text { is performing } \\
\text { the test }\end{array}$ & $\begin{array}{l}\text { Every batch } \\
\text { tested by this } \\
\text { method }\end{array}$ \\
\hline
\end{tabular}




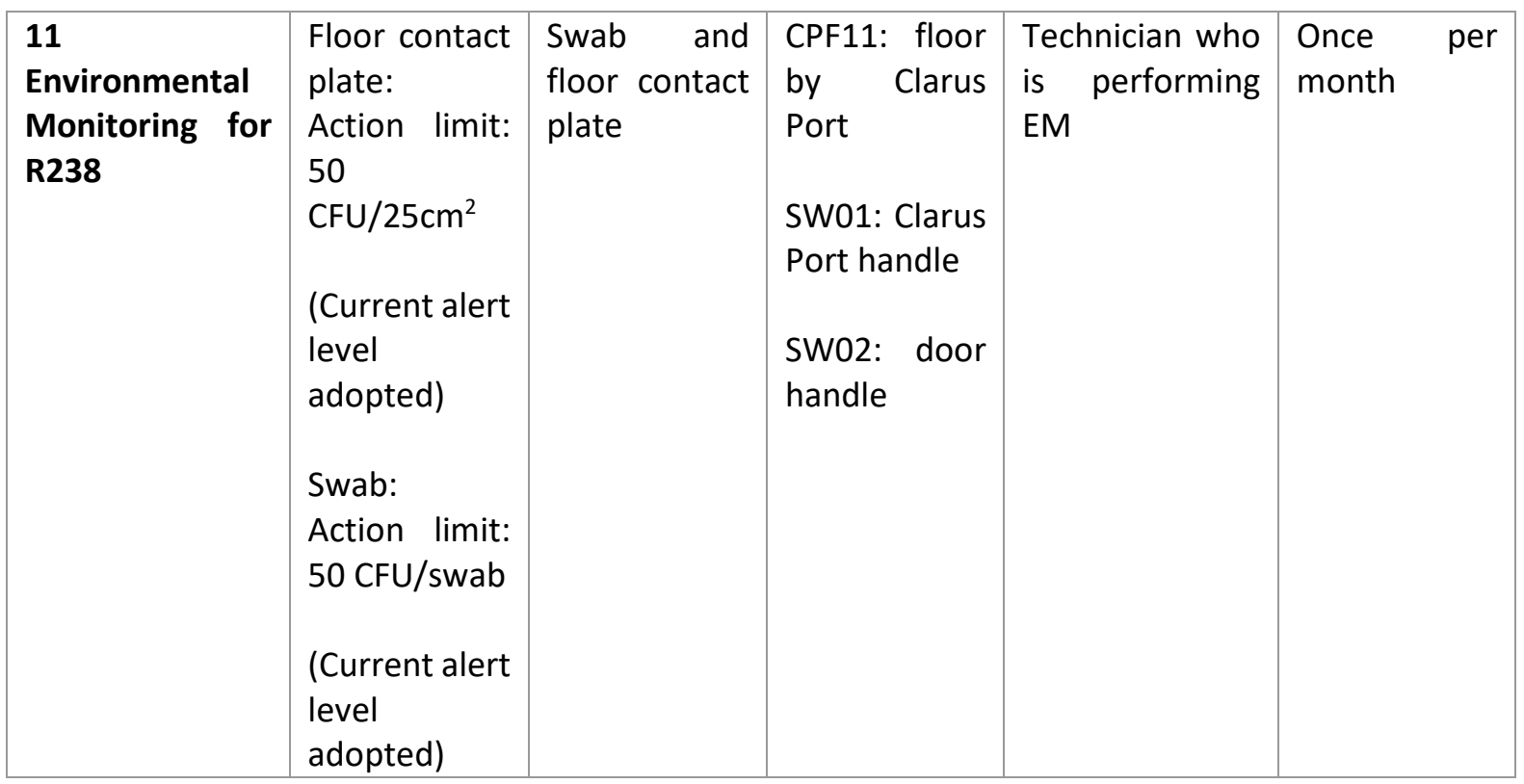

Key:

$\begin{array}{lll}\mathrm{SP} & = & \text { Settle plate } \\ \mathrm{CP} & = & \text { Contact plate } \\ \mathrm{SW} & = & \text { Swab }\end{array}$

Stage D: Map of Locations

Figure 6: Sampling plan for in-use state monitoring during sterility testing - membrane filtration right hand isolator 
Particle counter probe

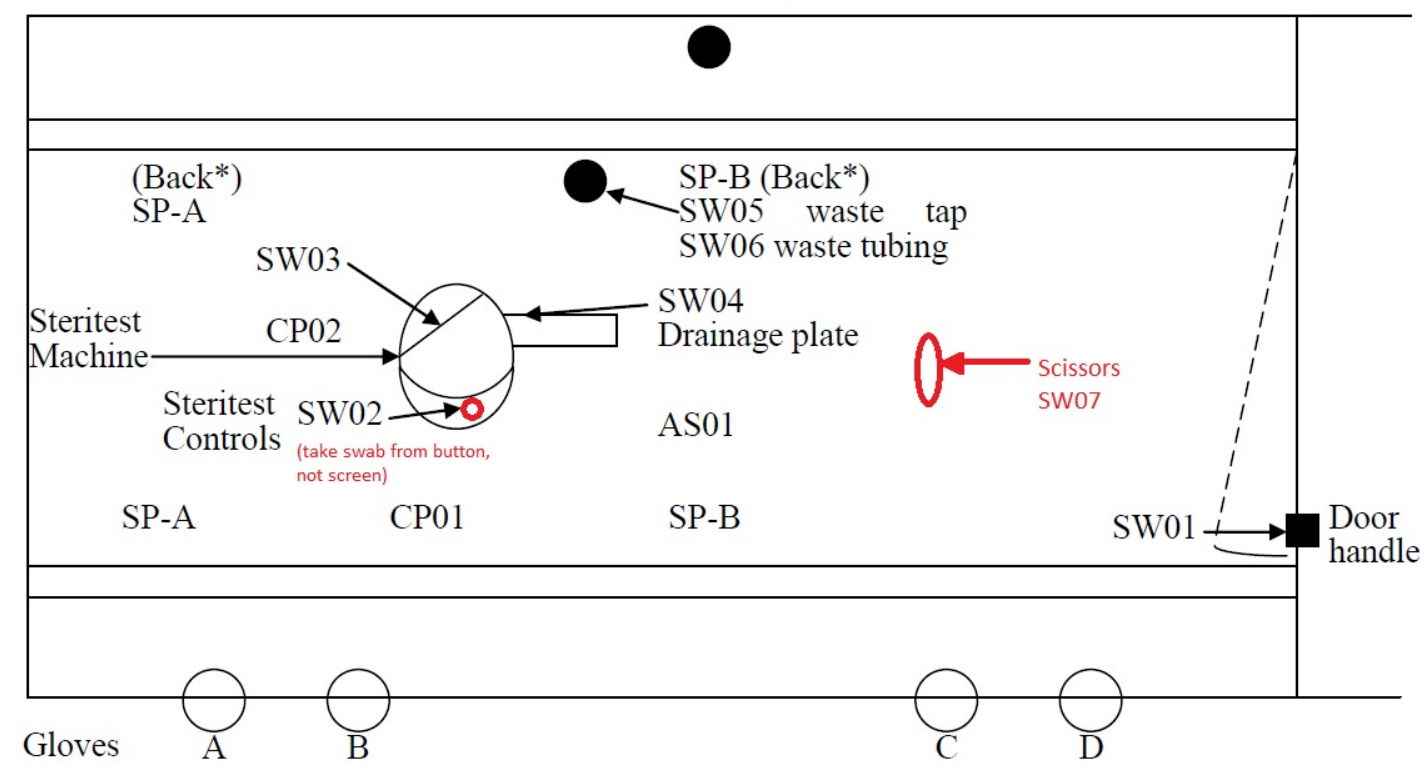


Figure 7: Sampling plan for in-use state monitoring during sterility testing - membrane filtration left hand isolator

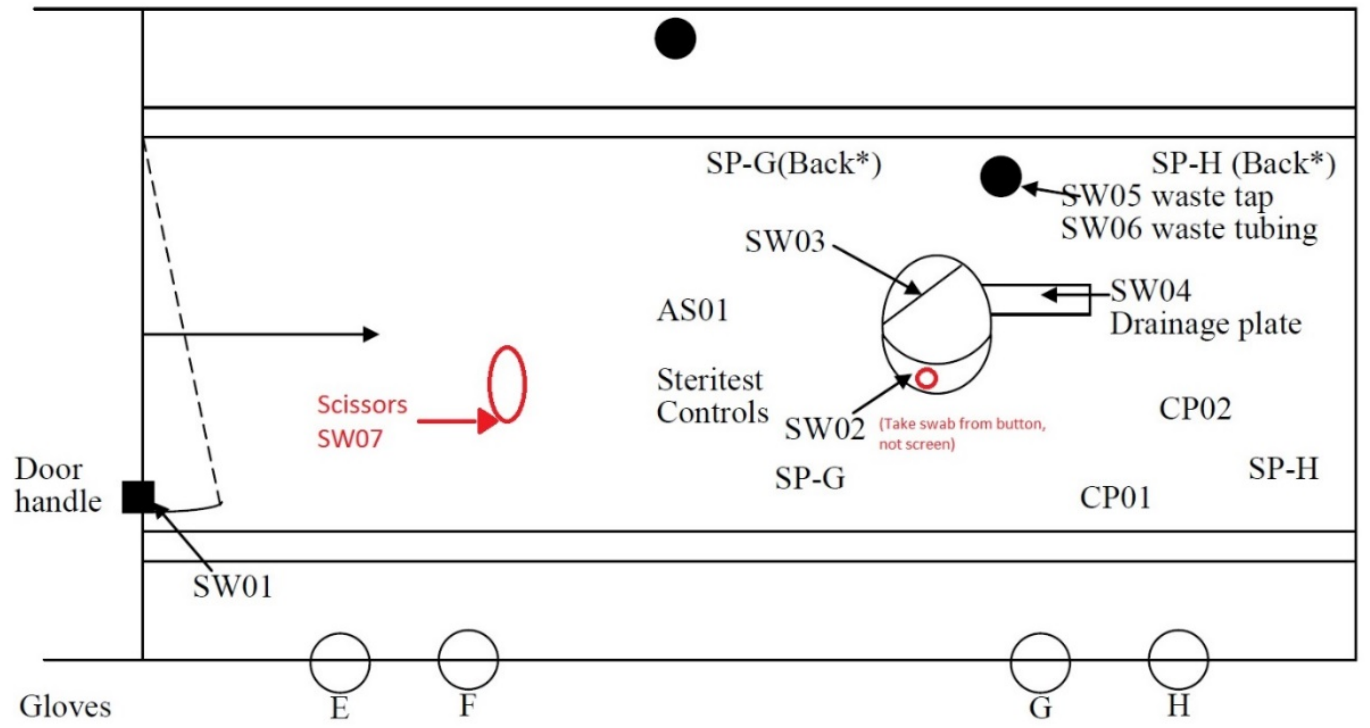


Figure 8: Sampling plan for in-use state monitoring during sterility testing - direct inoculation left hand isolator

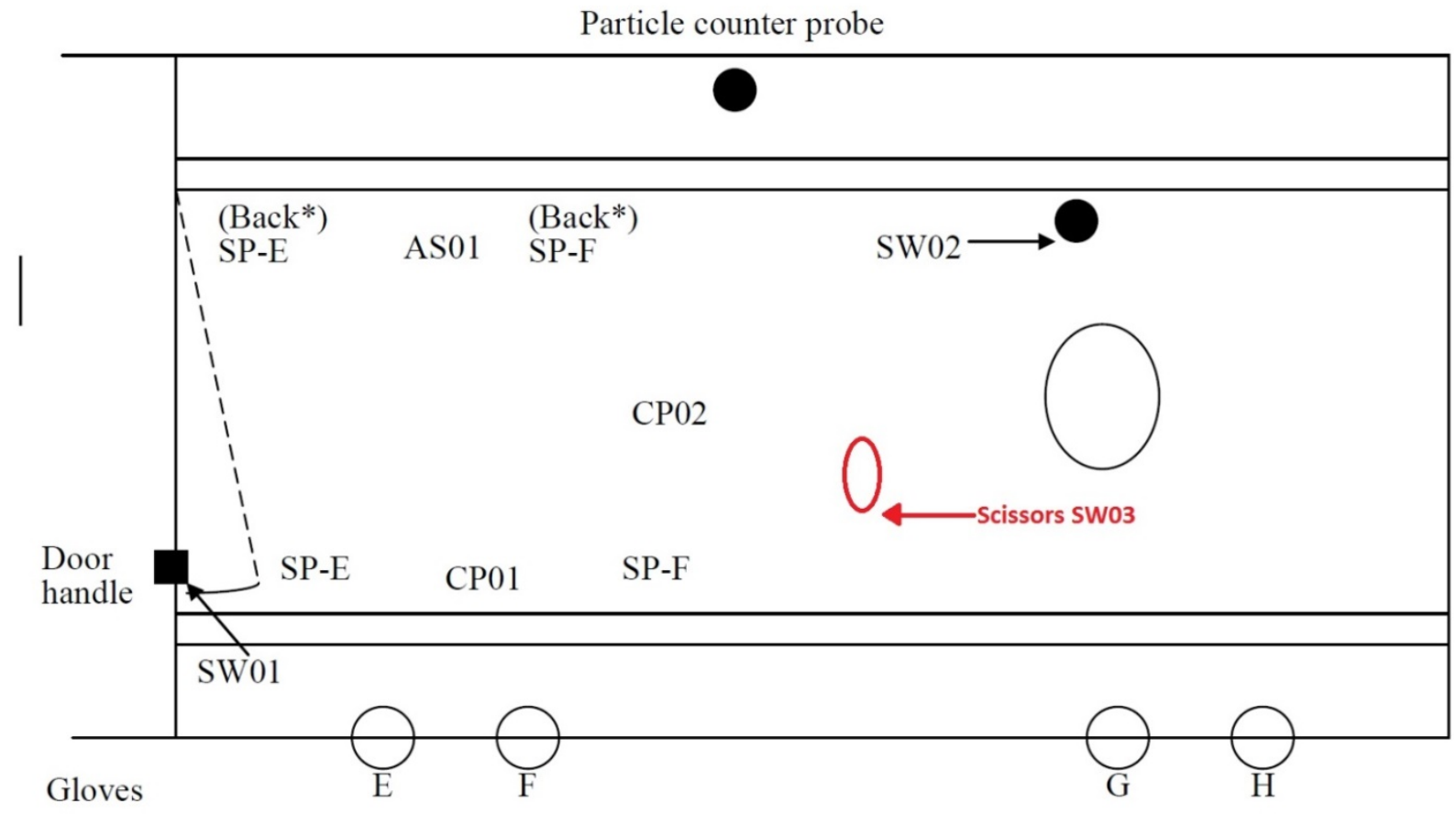


Figure 9: Sampling plan for in-use state monitoring during sterility testing - direct inoculation right hand isolator

Particle counter probe

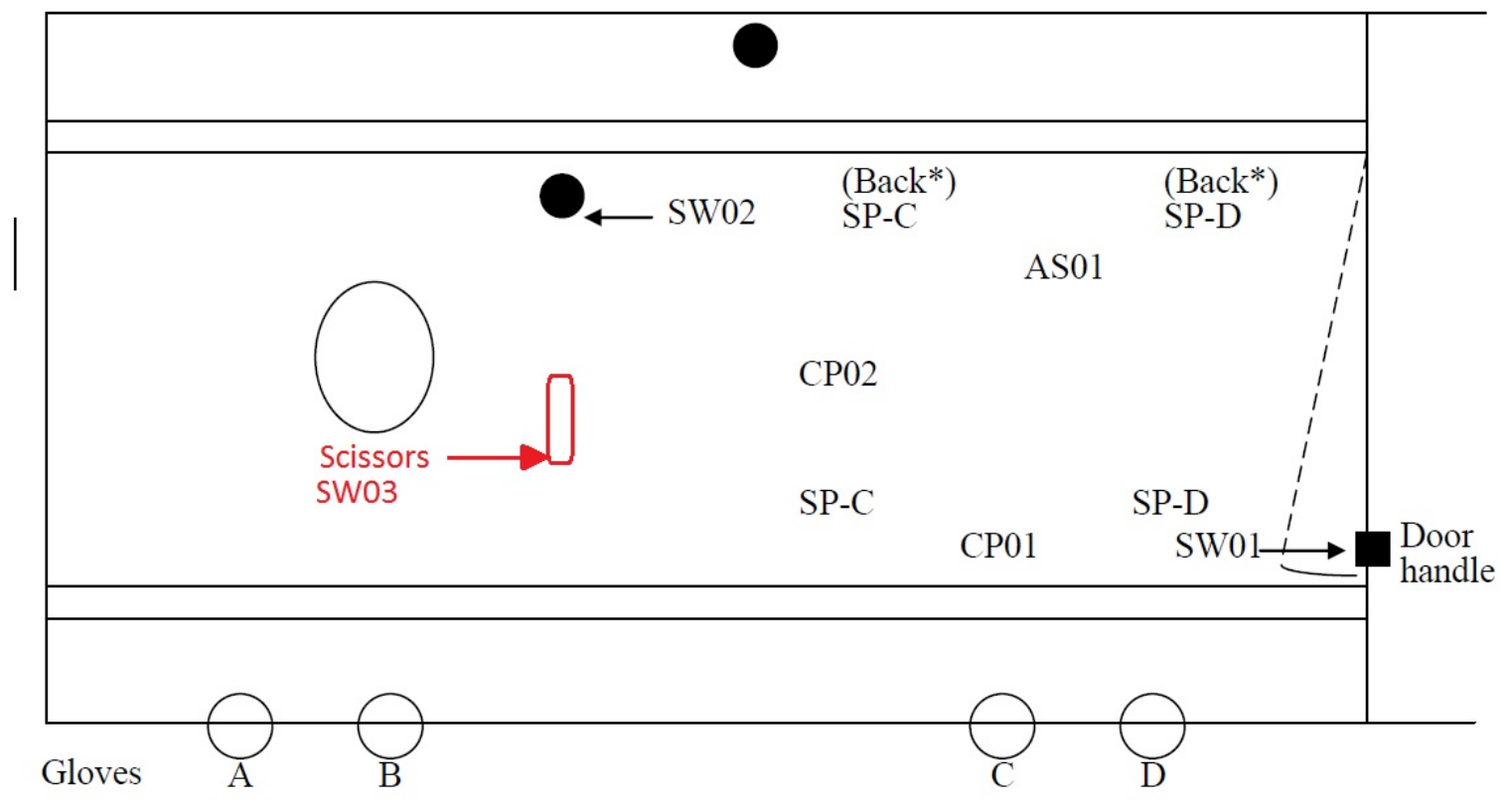


Figure 10: Isolator room routine environmental monitoring plan

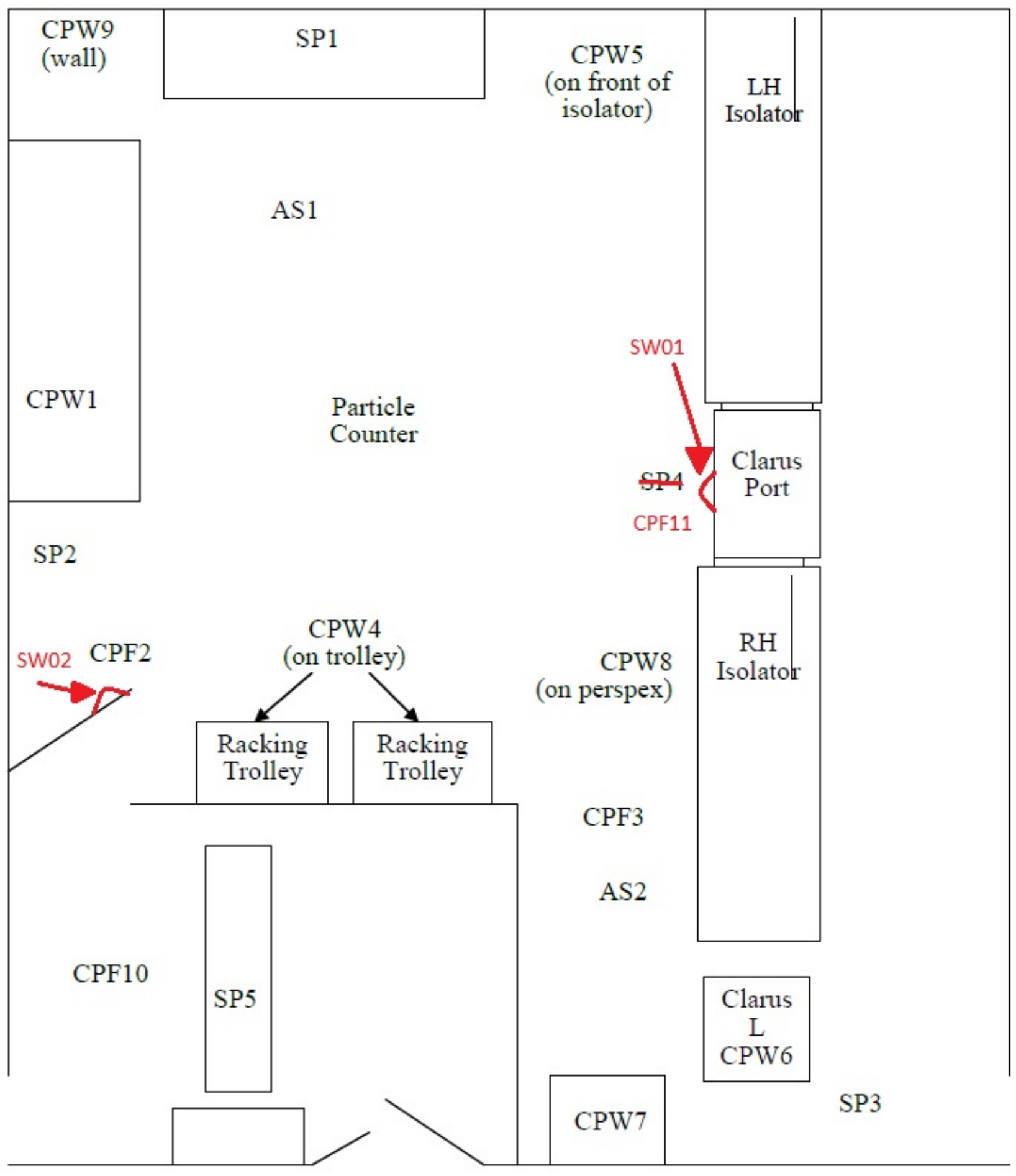


Figure 11: Sampling plan for dynamic state monitoring during hatch loading

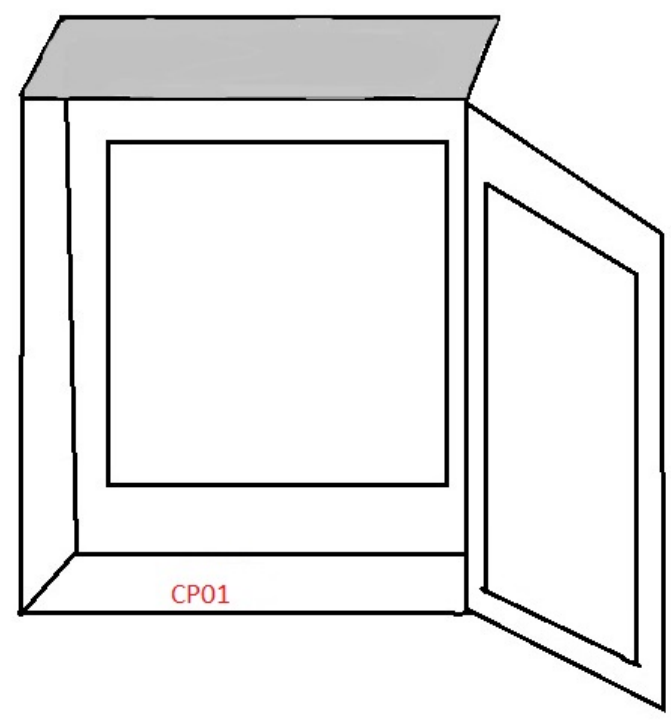

Key for figures 6 to 11 :

$\begin{array}{lll}\text { SP } & = & \text { Settle plate } \\ \text { AS } & = & \text { Air-sampler } \\ \mathrm{CP} & = & \text { Contact plate } \\ \mathrm{SW} & = & \text { Swab }\end{array}$


Stage E: Table 5: Actions to be taken in the event of an out-of-limits sample and the risk impact

Note: The table (Table 5) relates to all samples, not only the samples subject to review

\begin{tabular}{|c|c|c|c|c|c|c|}
\hline $\begin{array}{l}\text { Process step and } \\
\text { CCP identifier }\end{array}$ & $\begin{array}{l}\text { Risk to room / } \\
\text { isolator }\end{array}$ & Risk to product & $\begin{array}{l}\text { Identification of the } \\
\text { excursion }\end{array}$ & $\begin{array}{lr}\text { Control } & \text { measures } \\
\text { to } & \text { address } \\
\text { excursion } & \\
\end{array}$ & $\begin{array}{l}\text { Additional } \\
\text { monitoring }\end{array}$ & $\begin{array}{l}\text { Measures to } \\
\text { prevent } \\
\text { reoccurrence }\end{array}$ \\
\hline $\begin{array}{l}1 \text { Clean hatch } \\
2 \text { Items placed in } \\
\text { hatch } \\
3 \text { Remove items } \\
\text { from hatch }\end{array}$ & Serious & Serious & OOL sample & $\begin{array}{l}\text { Investigation to be } \\
\text { raised. } \\
\text { Assess cleaning and } \\
\text { disinfection } \\
\text { effectiveness of } \\
\text { hatch. } \\
\text { Assess sterility test } \\
\text { and sterility test } \\
\text { negative controls. }\end{array}$ & $\begin{array}{l}3 \text { repeats to be } \\
\text { taken }\end{array}$ & $\begin{array}{l}\text { It will be detailed on } \\
\mathrm{MI}\end{array}$ \\
\hline $\begin{array}{l}\text { Membrane } \\
\text { filtration test: } \\
7 \text { Environmental } \\
\text { monitoring during } \\
\text { batch testing } \\
8 \text { Environmental } \\
\text { monitoring post- } \\
\text { batch testing }\end{array}$ & Critical & Critical & OOL sample & $\begin{array}{l}\text { Investigation to be } \\
\text { raised. } \\
\text { Assess sterility test } \\
\text { and sterility test } \\
\text { negative controls. }\end{array}$ & $\begin{array}{l}\text { Post sanitisation } \\
\text { monitoring for each } \\
\text { isolator }\end{array}$ & $\begin{array}{l}\text { It will be detailed on } \\
\mathrm{MI}\end{array}$ \\
\hline $\begin{array}{l}\text { Direct inoculation } \\
\text { test: }\end{array}$ & Critical & Critical & OOL sample & $\begin{array}{l}\text { Investigation to be } \\
\text { raised. }\end{array}$ & $\begin{array}{l}\text { Post sanitisation } \\
\text { monitoring for each } \\
\text { isolator }\end{array}$ & $\begin{array}{l}\text { It will be detailed on } \\
\mathrm{MI}\end{array}$ \\
\hline
\end{tabular}




\begin{tabular}{|c|c|c|c|c|c|c|}
\hline $\begin{array}{l}\text { Process step and } \\
\text { CCP identifier }\end{array}$ & $\begin{array}{l}\text { Risk to room / } \\
\text { isolator }\end{array}$ & Risk to product & $\begin{array}{l}\text { Identification of the } \\
\text { excursion }\end{array}$ & $\begin{array}{lr}\text { Control measures } \\
\text { to } & \text { address } \\
\text { excursion } & \end{array}$ & $\begin{array}{l}\text { Additional } \\
\text { monitoring }\end{array}$ & $\begin{array}{l}\text { Measures to } \\
\text { prevent } \\
\text { reoccurrence }\end{array}$ \\
\hline $\begin{array}{l}7 \text { Environmental } \\
\text { monitoring during } \\
\text { batch testing } \\
8 \text { Environmental } \\
\text { monitoring post- } \\
\text { batch testing }\end{array}$ & & & & $\begin{array}{l}\text { Assess sterility test } \\
\text { and sterility test } \\
\text { negative controls. }\end{array}$ & & \\
\hline $\begin{array}{l}11 \text { Environmental } \\
\text { Monitoring for } \\
\text { R238 }\end{array}$ & Serious & Serious & OOL sample & $\begin{array}{l}\text { Investigation to be } \\
\text { raised and cleaning } \\
\text { and disinfection of } \\
\text { the room. } \\
\text { Assess sterility test } \\
\text { and sterility test } \\
\text { negative controls. }\end{array}$ & $\begin{array}{l}3 \text { repeats to be } \\
\text { taken }\end{array}$ & $\begin{array}{l}\text { It will be detailed on } \\
\mathrm{MI}\end{array}$ \\
\hline $\begin{array}{l}12 \text { Particle counting } \\
\text { in Grade A zone }\end{array}$ & Critical & Critical & $\begin{array}{l}\text { Particle count } \\
\text { excursions / upward } \\
\text { trend }\end{array}$ & $\begin{array}{l}\text { Investigation to be } \\
\text { raised. } \\
\text { Review HEPA filters } \\
\text { and other physical } \\
\text { measures. }\end{array}$ & $\begin{array}{l}\text { Clean device } \\
\text { certification } \\
\text { following remedial } \\
\text { action. }\end{array}$ & $\begin{array}{l}\text { It will be detailed on } \\
\text { MI e.g. preventative } \\
\text { maintenance of } \\
\text { HEPAs. }\end{array}$ \\
\hline $\begin{array}{l}13 \text { Particle counting } \\
\text { in isolator room }\end{array}$ & Serious & Serious & $\begin{array}{l}\text { Particle count } \\
\text { excursions / upward } \\
\text { trend }\end{array}$ & $\begin{array}{l}\text { Investigation to be } \\
\text { raised. } \\
\text { Review room } \\
\text { operations. }\end{array}$ & $\begin{array}{l}3 \text { repeats to be } \\
\text { taken } \\
\text { If a serious issue } \\
\text { arises and room } \\
\text { HEPAs need } \\
\text { replacing, then } \\
\text { cleanroom }\end{array}$ & $\begin{array}{l}\text { It will be detailed on } \\
\text { MI e.g. room } \\
\text { occupancy; room } \\
\text { activities; } \\
\text { preventative } \\
\text { maintenance } \\
\text { HEPAs. }\end{array}$ \\
\hline
\end{tabular}




\begin{tabular}{|l|l|l|l|l|l|}
\hline $\begin{array}{l}\text { Process step and } \\
\text { CCP identifier }\end{array}$ & $\begin{array}{l}\text { Risk to room / } \\
\text { isolator }\end{array}$ & Risk to product & $\begin{array}{l}\text { Identification of the } \\
\text { excursion }\end{array}$ & $\begin{array}{l}\text { Control measures } \\
\text { to } \\
\text { excursion }\end{array}$ & $\begin{array}{l}\text { Additional } \\
\text { address } \\
\text { monitoring } \\
\text { prevent } \\
\text { reoccurrence }\end{array}$ \\
\hline & & & $\begin{array}{l}\text { certification } \\
\text { following remedial } \\
\text { action. }\end{array}$ & \\
\hline
\end{tabular}

Should the isolator operation or associated activities undergo a change the HACCP will be reassessed to determine if any new hazards have arisen and whether any revisions are required to sample locations or frequencies. In addition, it is good practice to review the HACCP at periodic intervals. 


\section{Conclusion}

Despite widespread commentary in the pharmaceutical and healthcare industry and nudges from regulators, risk assessment still remains something that is spoken more about than something that is actually executed. This is also the case with contamination control. One reason is time (HACCP is lengthy and resource dependent, often requiring a multidisciplinary group); another is uncertainty; and a third is due to variety of different methods available, which makes it difficult to know which is the most suitable method for a particular risk assessment. The purpose of this paper was to present HACCP as an optimal method for biocontamination control - to review a process where microbiological risks are inherent, and to show how risk identification can aid hazard reduction and to select monitoring locations where a residual risk remains.

In doing so, the reader should note there are variations to HACCP and there are no hard-and-fast rules, provided that the HACCP concept and the seven principles are maintained. It should also be noted that the case study presented is illustrative; nothing in this paper should simply be copied over, the idea is to present an approach against which facility-based HACCPs can be benchmarked against. Whether HACCP is always the right tool also needs to be weighed up. In most cases of biocontamination control assessment, in the opinion of the authors, it will be; however, as Peacos points out (35) the risk tool selected must be appropriate for the type of process under consideration, and the level of formality of the risk assessment tool appropriate for the complexity of the process being assessed.

The authors hope that the advantages of a structured method for risk assessment has been presented clearly. Approaches like HACCP can lead to a reduction of variability and can guide microbiologists and others to attend to relevant information in a systematic way.

HACCP should ideally be used as a prospective risk assessment tool. In pharmaceuticals and healthcare there is an over-reliance upon retrospective methods, including incident reporting, root cause analysis, to identify risks. Retrospective methods address problems after they have occurred, rather than preventing them prospectively. Therefore, it is recommended that tools like HACCP are used to review existing processes and ensure that risks are minimized and that environmental monitoring locations are the most suitable for the assessment of risks.

Even with the identification of critical control points and the use of environmental monitoring, most data is only obtained sometime after events have happened. This is gradually being redressed through the development of rapid microbiological methods; the newer generation of methods, which permit real-time (or at least, faster time-to-result) fit well with the HACCP framework and will only strengthen the risk detectability power of the HACCP approach.

A final comment is that running a HACCP is no absolute guarantee of reliability or validity. The data generated must be reviewed, trends reacted to and the HACCP reviewed in relation to the trends. A control breakdown may have occurred, which can be addressed, or the HACCP itself may have been imperfect and needs to be re-run. In addition, HACCPs should be regularly reviewed and taken account of when changes to process occur. Ideally, each change control should trigger a re-examination of the associated risk assessment. 


\section{References}

1. Sandle, T. (2016) Risk Assessment and Management for Healthcare Manufacturing: Practical Tips and Case Studies, PDA / DHI, Bethesda, MD, USA, pp1-10

2. McFarland, A. B. and Waldron, K. (2015) Considerations Regarding the Use of Detectability In Risk Assessments, Journal of Validation Technology, 21 (4): 1-8

3. Sutton, S. V. (2010) The Environmental Monitoring Programme In a GMP Environment, Journal of GXP Compliance, 14 (3): 22-30

4. Bennet L. and Steed L. (1999) An integrated approach to food safety. Qual. Progr. 32, 37-42

5. Ross-Nazzal, J. (2007) From farm to fork: How space food standards impacted the food industry and changed food safety standards. In S. J. Dick and R. D. Launius (Eds.) Societal Impact of Spaceflight, Washington, DC: NASA, pp 219-236

6. Sandrou K. and Arvanitoyannis S. (2000) Application of hazard analysis critical control point (HACCP) system to the cheese-making industry: a review. Food Reviews International 16(3): 327-368

7. National Research Council (US) Subcommittee on Microbiological Criteria. An Evaluation of the Role of Microbiological Criteria for Foods and Food Ingredients, Washington (DC): National Academies Press (US); 1985

8. Anon. Recommendations of the US National Advisory Committee on Microbiological Criteria for Foods: I HACCP principles, II meat and poultry, III seafood, Food Control, 2 (4): 202-211, 1991

9. ICMSF (International Commission on Microbiological Specifications for Foods). Microorganisms in Foods, Vol. 4: Application of the Hazard Analysis Critical Control Point System to Ensure Microbiological Safety and Quality (v. 4), Søltofts Plads, Denmark, 1989

10. Woodcock J. (2004) The concept of pharmaceutical quality. American Pharmaceutical Review. 7(60):10-15

11. Mitchell, I., Schuster, A., Smith, K., Pronovost, P. and Wu, A. (2016) Patient safety incident reporting: a qualitative study of thoughts and perceptions of experts 15 years after 'To Err is Human', BMJ Quality \& Safety, 25, 2, (92)

12. Gervais, B. and D'Arcy, D. M. (2014) Quality risk analysis in a cGMP environment: multiple models for comprehensive failure mode identification during the computer system lifecycle, Drug Development and Industrial Pharmacy, 40 (1): 46-60

13. Jagals, C. and Jagals, P. (2004) Application of HACCP principles as a management tool for monitoring and controlling microbiological hazards in water treatment facilities, Water Sci Technol. 50(1):69-76

14. Jahnke, M. and Kühn, K.D. (2003) Use of the Hazard Analysis and Critical Control Points (HACCP) Risk Assessment on a Medical Device for Parenteral Application, PDA J Pharm Sci Technol.; 57(1):32-42

15. Satyada, R. and Sandle, T. (2018) Rationale for the selection of microbial monitoring locations on personnel working in aseptic processing areas, European Journal of Pharmaceutical Science and Technology, 23 91): 17-23

16. McFarland, A. B. (2018) Risk-Based Microbial Assessment Tool (R-MAT): A Novel Approach to Assessing Environmental and Critical Utilities Excursions, American Pharmaceutical Review, Volume 21, accessed $10^{\text {th }}$ June 2018, at:

https://www.americanpharmaceuticalreview.com/Featured-Articles/347219-Risk-BasedMicrobial-Assessment-Tool-R-MAT-A-Novel-Approach-to-Assessing-Environmental-andCritical-Utilities-Excursions/ 
17. Ziegler, I., Borbély-Jakab, J., Sugó, L., Kovács, R. J. (2017): Revision of Viable Environmental Monitoring in a Development Pilot Plant Based on Quality Risk Assessment: A Case Study, PDA J Pharm Sci Technol.;71(3):234-244

18. Sandle, T. (2015a): Aseptic Transfer Risk Assessment: A Case Study, Journal of Validation Technology, 21(1): 1-10

19. Sandle, T. (2015b) Current Methods and Approaches for Viral Clearance, American Pharmaceutical Review, September / October, Volume 18, 2015: 1-4, accessed $10^{\text {th }}$ June 2018, at: https://www.americanpharmaceuticalreview.com/Featured-Articles/179320Current-Methods-and-Approaches-for-Viral-Clearance/

20. Annalaura, C., Giulia, D. and Stefano, C. (2013) The application of quality risk management to the bacterial endotoxins test: use of hazard analysis and critical control points, PDA J Pharm Sci Technol.;67(5):553-67

21. Sandle, T. (2013a): Risk assessment and monitoring of cleanrooms, Hospital Pharmacy Europe, May / June 2013, pp54-56

22. Sandle, T. (2012). Application of Quality Risk Management To Set Viable Environmental Monitoring Frequencies in Biotechnology Processing and Support Areas, PDA Journal of Pharmaceutical Science and Technology, 66 (6): 560 - 579

23. Singer, D. (2012) A Strategy for Developing Robust Pharmaceutical Microbiological Control, American Pharmaceutical Review, Volume 15, accessed $10^{\text {th }}$ June 2018, at:

https://www.americanpharmaceuticalreview.com/Featured-Articles/119444-A-Strategy-forDeveloping-Robust-Pharmaceutical-Microbiological-Control/

24. Sandle, T. (2011): 'Risk Management in Pharmaceutical Microbiology' in Saghee, M.R., Sandle, T. and Tidswell, E.C. (Eds.) (2011): Microbiology and Sterility Assurance in Pharmaceuticals and Medical Devices, New Delhi: Business Horizons, pp553-588

25. Bissett, L. (2010) Developing decontamination strategies and monitoring tools, $\mathrm{Br} J$ Nurs.;19(16): S12-7

26. Bonan, B., Martelli, N., Berhoune, M., Maestroni, M.L., Havard, L. and Prognon, P. (2009) The application of hazard analysis and critical control points and risk management in the preparation of anti-cancer drugs, Int I Qual Health Care.;21(1):44-50

27. Ashtekar, D. (2005) Microbiological Risk Analysis. In Moldenhauer, J. (Ed.) Environmental Monitoring: A Comprehensive Handbook, Volume 1, DHI/PDA books, pp281-306

28. Whyte, W., and Eaton, T. (2002) A cleanroom contamination control system. European Journal of Parenteral and Pharmaceutical Sciences, 7 (2): 55-61

29. Jahnke, M. (1997) Use of the HACCP concept for the risk analysis of pharmaceutical manufacturing process. European Journal of Parenteral Sciences; 2(4): 113-117

30. Isoard, P., Vidal, D., Thibault, F. and Ducel, G. (1993) Biocontamination, European standardization and pharmaceutical industry, Ann Pharm Fr.;51(4):186-96

31. Canadian Food Inspection Agency (CFIA). 2014. Food Safety Enhancement Programme Manual. Retrieved 10th June 2018, at: http://www.inspection.gc.ca/DAM/DAM-foodaliments/STAGING/text-texte/food fsep man 1343667674768 eng.pdf

32. Greene, A. and O'Donnell, K. (2006) A Risk Management Solution Designed to Facilitate RiskBased Qualification, Validation, and Change Control Activities within GMP and Pharmaceutical Regulatory Compliance Environments in the EU-Part I, white paper hosted by the Institute of Validation Technology (IVT), access on $10^{\text {th }}$ June 2018 , at: http://www.ivtnetwork.com/article/risk-management-solution-designed-facilitate-riskbased-qualification-validation-and-change-

33. World Health Organization. (2003). Application of Hazard Analysis and Critical Control Point (HACCP) Methodology to Pharmaceuticals (Annex 7).WHO Expert Committee on Specifications for Pharmaceutical Preparations 
34. Sandle, T. (2013b). Contamination Control Risk Assessment. In Masden, R.E. and Moldenhauer, J. (Eds.) Contamination Control in Healthcare Product Manufacturing, Volume 1, DHI Publishing, River Grove: USA, pp423-474

35. Peacos, P. (2016) Bias: The Hidden Danger to Your Risk Assessment, American Pharmaceutical Review, Volume 19, accessed $10^{\text {th }}$ June 2018, at:

https://www.americanpharmaceuticalreview.com/Featured-Articles/184365-Bias-TheHidden-Danger-to-Your-Risk-Assessment/ 